\title{
Theorizing command-and-commodify regulation: the case of species conservation banking in the United States*
}

Christopher M. Rea

University of California, Los Angeles

State-directed but market-oriented forms of regulation, especially environmental examples like cap-and-trade and ecological offsetting, have proliferated in the past two decades, but sociologists have been slow to theorize these broad institutional shifts. This article offers a framework for explaining these processes of regulatory marketization. First, I argue that institutions of this sort are examples of what I call command-and-commodify regulation, a mode of regulation that distinctively hybridizes economic and authoritative dimensions of power. Second, I explain how and why one example of command-and-commodify regulation, species conservation banking, emerged and remained concentrated in California, but did not so easily develop in other American states. Finally, abstracting from the case, I argue that the concept of market reconstruction is useful for developing a more general theory of the ways that social conflicts and mobilization reconfigure regulatory power, and thus give rise to new modes of regulation. Together, a theory of command-and-commodify regulation and market reconstruction may be useful for explaining the development of a wide variety of environmentally focused and other regulatory institutions.

Keywords: markets, commodification, regulation, institutional emergence, environment, endangered species

Forthcoming in Theory \& Society

\author{
Contact \\ Christopher M. Rea \\ Department of Sociology \\ 264 Haines Hall \\ Box 91551 \\ Los Angeles, CA 90095-1551 \\ christophermrea [at] gmail.com
}

\footnotetext{
*Special thanks to Thomas Angeletti, Tim Bartley, Jens Beckert, Fred Block, Winston Chou, Guus Dix, Rebecca Emigh, Jenny Goldstein, Neil Gong, Hannah Landecker, Ching Kwan Lee, Yewon Lee, Michael Mann, Bill Roy, Ksenia Varlyguina, Ed Walker, two anonymous reviewers and the Editors at Theory \& Society, and the participants of the UCLA Comparative Social Analysis seminar for many helpful comments and ideas that contributed to this paper. Anonymous reviewers in a previous review process were also very helpful. The research presented in this article was developed in part under GRO Fellowship Assistance Agreement no. F13A10071 awarded by the U.S. Environmental Protection Agency (EPA). It has not been formally reviewed by EPA. The views expressed in this article are solely those of the author.
} 


\section{Theorizing command-and-commodify regulation: the case of species conservation banking in the United States}

Gazing out over the grasslands of Valley Flats Reserve, just outside of Sacramento, California, one would not suspect that one is looking at an example of an important and far reaching development in environmental regulation - one that speaks to broader shifts in the ways that states wield regulatory power, and use markets to achieve specific regulatory ends.

But Valley Flats is unusual. Only a few short years ago it was a heavily cultivated agricultural field. Now, as an ecologically restored species conservation bank, Valley Flats is effectively a supply center in a thriving marketplace for an unusual commodity: endangered species credits. These are fungible units of endangered species habitat offered for sale in order to satisfy government-imposed requirements for land developers to "offset" the "unavoidable" impacts caused by their building projects. When a road widening plan or housing development will cause harm to endangered species habitat, species conservation banks like Valley Flats are the places that land developers go to buy units of preserved land-typically for tens or hundreds of thousands of dollars per acre - in order to help 'make up' for the ecological harm caused by the road widening or house building. The brushy shrubs and subtle wetland swales of Valley Flats Reserve, and the endangered valley elderberry longhorn beetles and vernal pool fairy shrimp that call them home, are thus physical instantiations of a growing institutional trend: the marketization of environmental regulation, and more specifically, the integration of markets - in this case markets for endangered species credits - into state-directed regulatory regimes of all kinds, environmentally focused and otherwise.

Examples of this trend are widespread. In the early 1990s, regulatory-driven exchanges in pollution or trades in units of ecology were all but unheard of. Now, however, in the 2010s, states have built regulatory markets in all manner of "peculiar goods" (Fourcade 2011), like carbon credits (Engels 2006; Tietenburg 2006), wetland credits (Robertson 2004, 2006; Lave 2012b), sulfur dioxide credits (Ellerman et al. 2000; Levin and Espeland 2002), and of course, endangered species credits (Fox and Nino-Murcia 2005; Carroll et al. 2009). This is to say nothing of other non-environmental examples, like auctions in frequency spectra used to regulate bandwidth allocations in telecommunications (Vogel 2016), or state-controlled healthcare marketplaces established in the United States under the Patient Protection and Affordable Care Act (Obama 2016).

This regulatory trend is also international. Habitat offsetting schemes, like wetland mitigation banking and species conservation banking in the United States, are also under study or in use in Canada, the United Kingdom, Australia, Germany, France, the Netherlands, Malaysia, and Brazil; the European Union as a whole is considering implementing such a system. ${ }^{1}$ Emissions trading is also proliferating. The most well known (and heavily critiqued) example of a carbonbased cap-and-trade scheme is the European Union Emissions Trading Scheme (cf. Tietenburg 2006; Meckling 2011), but some of the world's other largest greenhouse gas emitters, like China, India, and South Korea, have recently (or are currently) rolling out cap-and-trade programs (World Bank 2014). Japan (in Tokyo), Canada (in Quebec), and the United States (in California and in the Northeast) all have sub-national cap-and-trade programs. The new state-directed but

${ }^{1}$ For a brief exposition of habitat offsetting, see Robertson (2004) (for wetlands) or Carroll et al. (2009) (for endangered species). For a brief overview of cap-and-trade systems see MacKenzie (2009), or for more details, Tietenburg (2006). 
market-oriented regulatory institutions I consider in this article, in short, are quickly becoming not just a keystone of environmental regulation, but an important element of regulation in many policy domains, and are doing so across the globe.

What, then, can an example like Valley Flats, and the case of species conservation banking in general, reveal about both the institutional character and political-historical genesis of these new state-directed but market-oriented modes of regulation? The answer comes in two parts.

First, a study of the emergence of species conservation banking in the United States offers an opportunity to develop a concise and essential description of the basic sociological features of state-directed but market-oriented regulatory institutions. Of course discussions and investigations of things like regulatory marketization, "reregulation," and market-oriented "new policy instruments" are well-worn in social science (Kettl 1993; Vogel 1996; Golub 1998; Kettl 2002); the fiction of markets 'free' from state intervention is now widely recognized (Polanyi 2001; Fligstein 2001), and the more specific idea of building markets to internalize various externalities, especially environmental ones, is more than a half-century old (Coase 1960; Dales 1968a,b).

But researchers - and sociologists in particular ${ }^{2}$ - have been slow to offer a concise accounting of what makes state-directed but market-oriented forms of regulation distinctive as institutions, for example, by clearly articulating how something like species conservation banking or cap-and-trade is different from other kinds of markets, as well as from other forms of state-directed regulation. Accounts of these institutions that do exist, both within and beyond sociology, typically focus instead on processes of commodification and capitalization (e.g. Levin and Espeland 2002; MacKenzie 2009), and often emphasize the functions these new markets may serve, such as 'greening' capitalism (Mol and Sonnenfeld 2000; Mol and Spaargaren 2000; Spaargaren and Mol 2013) or providing a new, neoliberal means of accumulating capital (Clark and York 2005; Castree 2008; Foster et al. 2009; Brockington and Duffy 2010; Büscher et al. 2012). Recent political-institutional approaches typically avoid functional explanations, but have focused more on the rise of non-state and "private" forms of regulation (e.g. Vogel 2005; Bartley 2007; Soule 2009; Locke 2013) than on these distinctive state-directed but market-oriented regulatory forms. A handful of sociological studies of emissions trading are an important exception (Levin and Espeland 2002; Engels 2006; Schneiberg and Bartley 2008; MacKenzie 2009; Lohmann 2010; Lederer 2012; Spaargaren and Mol 2013), but again, these accounts do not theorize the ways that different institutions like cap-and-trade and species conservation banking may be distinct examples of a more general state-directed but market-oriented regulatory form.

In the first half of this article, then, I use case of species conservation banking in order to characterize the key sociological features of these increasingly common and hybrid institutions, which integrate elements of both 'free' markets and stringent, top-down state control. This unusual hybridity, I argue, points to a more general feature of state-directed but market-oriented forms of regulation: these institutions wield regulatory power by combining what Weber (1978: 943) identified as "two diametrically contrasting types of domination," namely domination by economic power, on the one hand, and domination by authority, on the other (see also Swedberg

\footnotetext{
${ }^{2}$ Levin and Espeland (2002), Engels (2006), Schneiberg and Bartley (2008), MacKenzie (2009), and Spaargaren and Mol (2013) are among the few sociologists who take these market-oriented forms of regulation as direct objects of analysis. Tellingly, with the exception of a discussion of tradable quotas used in fisheries, a recent review of sociological scholarship on "The Political Economy of the Environment" (Rudel et al. 2011) does not mention any form of state-directed but market-oriented environmental regulation.
} 
2005: 233; Roy 1997: 13-14). Species conservation banking and its numerous institutional siblings are thus neither examples of old-fashioned command-and-control regulation (Sinclair 1997) — which relies primarily on authoritative commands - nor examples of more recently discussed private or self-regulation (Schneiberg and Bartley 2008; Locke 2013) —which shapes social action primarily by reconfiguring incentive structures in markets. Rather, institutions like species conservation banking and cap-and-trade are better understood as an example of a distinctive institutional form of their own-one that I will call command-and-commodify regulation exactly because of the way it brings authoritative and economic dimensions of power together under a single institutional roof.

The second opportunity offered by the case of species conservation banking is in accounting for the general political-historical dynamics that are necessary for such command-andcommodify institutions to emerge. The case of species conservation banking turns out to be especially well suited for this kind of analysis. Most examples of command-and-commodify regulation, such as cap-and-trade schemes and mandatory insurance markets, are legislated directly into existence. This means that however controversial and contested they may have been - and they are often very controversial (e.g. McCright and Dunlap 2003; Meckling 2011; Obama 2016) - their formal-legal codification ultimately leads to a relatively quick and uniform process of institutional diffusion, making it much more difficult for a social scientist to identify and trace the particular political and historical processes that lead to their emergence (or nonemergence) in specific times and places.

But species conservation banking is an exception. This particular example of command-andcommodify regulation draws its legal legitimacy most fundamentally from the United States Endangered Species Act - a federal law originally passed in 1973 to protect endangered species, but never intended to create species conservation banks. As data below will make clear, differences in the interpretation and implementation of this law centrally (but not singularly) explain where and how species conservation banking has emerged across the United States. Starting in the mid-1990s in California, regulatory reinterpretations of the federal Endangered Species Act made it possible to create species conservation banks there. In most other states, however, more conventional interpretations of the law held firm, and species conservation banking did not proliferate in those places. As a result, of the 137 species conservation banks that had been approved in 2014 (figure 1), 110 (80\%) of them were concentrated in California (figure 2).

\section{[Figure 1 about here]}

\section{[Figure 2 about here]}

Species conservation banking thus provides an unusual opportunity to investigate the political-historical dynamics that drive the shifts in regulatory power required for command-andcommodify institutions to emerge. The incremental and legally ambiguous nature of these policy changes in this particular case make it similar to what Merton (1987) would call a "strategic research site," wherein the conflicts, struggles, and compromises of environmental policy and politics in California are 'slowed down' and become uniquely visible for study, and observations of these processes can then be set against comparable dynamics in other states, where species conservation banking did not so easily emerge. By comparing what happened in California to what did not happen in other states, it becomes possible to discover how, exactly, a new 
regulatory form was born, with implications for understanding similar processes of institutional emergence and regulatory change in other contexts.

In the sections to follow, I first briefly outline the data and methods I use for this study. Turning to the first major part of the article, I then describe the case of species conservation in slightly more detail, before highlighting the policy and scholarly disagreements over how to best understand these and similar institutions. Given this conceptual ambiguity, I develop the command-and-commodify framework as a means of more clearly understanding the distinctive character - and in particular, the configurations of power - of these regulatory institutions. In the next major section I turn back to the case of species conservation banking in detail, in order to explain specifically how and why this particular example of command-and-commodify regulation emerged in California, and why it did not emerge in other states. In this discussion, I focus first on the dynamics that shifted authoritative forms of regulatory power before turning my attention to concomitant shifts in economic power that were also necessary for species conservation banking to develop. In the third section I abstract from the specifics of the empirical case in order to show how, by tracing shifts in economic and authoritative dimensions of power, it becomes possible to explain patterns of institutional emergence and regulatory change more generally. I conclude by summarizing the contributions of this study to economic, organizational, and environmental social science.

\section{A Note on Data}

The analysis that follows depends to some degree on archival and quantitative data related to economic growth, endangered species protection, and environmental-legal disputes. My chief data source, however, is a combination of ethnographic fieldwork and semi-structured, in-depth interviews. Ethnographic participant observation included interacting with environmental regulators and species conservation "bankers" at three national conferences, presenting preliminary research at one conference, and riding along on one-on-one tours of species conservation banks. Interviews were conducted with 50 key informants from around the United States, many of whom were instrumental in developing the first species conservation banks in their region, and most of whom work directly with creating or regulating these institutions. ${ }^{3}$ Interviews were conducted to the point of saturation (Small 2009: 25) not to analyze informant discourse or assertion meanings associated with observed actions, but rather to assemble a collective accounting of the social-historical conditions, practices, and policies that have either promoted or inhibited the emergence of species conservation banks since the mid-1990s. Interviews were thus both historical and ethnographic, focused on events, actions, and practices more than on meanings and interpretations (although these categories are entangled). Interviews varied from just over 20 minutes to almost three hours and were conducted in 2012 and the winter of 2014-2015. The average interview duration was just over 70 minutes. All but five interviews were recorded and fully transcribed. Representative quotes were selected to highlight clear patterns and historically significant processes regularly brought up by informants.

\section{Characterizing an institution}

To begin with, it is essential to understand exactly what species conservation banks are, and what they are not. While these institutions are designed to generate profits, species conservation banks

\footnotetext{
${ }^{3}$ Table A1 catalogues my informants by organizational affiliation and geographic region of expertise.
} 
are not financial institutions. They are instead sizable tracts of land where endangered species habitat is restored or preserved ('banked'). These banks then sell units of habitat called species credits to land developers who are required by government regulators to "mitigate" (or 'offset') for harming existing species or habitat nearby. In California, credits for endangered vernal pool fairy shrimp typically sell for $\$ 200,000$ to $\$ 300,000$ per acre. ${ }^{4}$ In Florida, as part of a highway expansion project, a county commission recently paid \$1.9 million for roughly 1,500 panther habitat units. ${ }^{5}$ Species conservation banking, in short, is a quintessential example of the statedirected but market-oriented institutions that I focus on in this article: it deploys new stateimposed limits on the ability of land developers to harm endangered species habitat, in the form of requirements for endangered species offsets, but it also reshapes economic action by creating a market in such offset credits, such that using land and harming habitat is in part discouraged via the costs that species credits impose.

\section{Diverging accounts and uncooperative empirics}

It is essential to emphasize that there is great uncertainty in the political and policy worlds about these new command-and-commodify modes of regulation. Lesser-known cap-and-trade programs, such the American market in sulfur dioxide (a key component of acid rain), are regularly held up as tremendous policy successes, and as proofs of concept (Ellerman et al. 2000; Tietenburg 2006). Flagship examples of these institutions, however, like the EU Emissions Trading Scheme and, more recently, the California Cap and Trade program, have struggled when prices for carbon credits collapsed in the face of oversupply, and have also faced problems with perverse incentives, cheating, and non-compliance (Ellerman and Buchner 2007; Meckling 2011). Outside of climate, so-called biodiversity offsetting schemes in the United Kingdom have so far failed to develop beyond pilot programs because of resistance from both the political right and the left (Lockhart 2015). My own data makes clear that species conservation banking in the United States was itself initially viewed with skepticism by many environmental groups and environmental regulators. As one informant put it bluntly,

...this 'banking' idea came on and all the environmentalists hated it. The agencies all hated it [too], because they were really afraid it was going to facilitate development $(3 / 21 / 12)$.

Academic researchers are also split about how to understand these new forms of regulation. For economic and ecological optimists, who often subscribe to some form of ecological modernization theory, these new institutions represent crucial and encouraging efforts to make capitalist relationships with nature sustainable. Drawing theoretical support from the notion of a "risk society" (Beck 1992) and especially reflexive modernization (Beck et al. 1994; cf.Buttel 2000), some environmental sociologists argue that citizens and leaders, increasingly alarmed by very real and pressing environmental problems, are "redirecting and transforming 'free market capitalism' in such a way that it less and less obstructs, and increasingly contributes to, the preservation of [the environment]" (Mol and Spaargaren 2000: 23; see also Mol and Sonnenfeld

\footnotetext{
${ }^{4}$ See "Madera Pools Restoration and Mitigation Site," California Department of Transportation (2011) and Lamb (2007).

${ }^{5}$ See Collier County Board of County Commissioners meeting, May 24, 2011, agenda item 10.C. Video archive available at http://www.colliergov.net/index.aspx?page=2280
} 
2000). Institutions like species conservation banking and cap-and-trade, which internalize environmental externalities, are prime examples (Mol 2012; Spaargaren and Mol 2013; cf. Bailey et al. 2011).

But other researchers are much less optimistic. Critical approaches in environmental sociology and political ecology suggest an alternative account, arguing that market-oriented institutions like species conservation banking are part of a neoliberal project to reregulate human relationships with nature in ways that enrich capitalists and that serve as "environmental fixes" to crises of accumulation in other economic sectors (Bakker 2005; Swyngedouw 2005; Smith 2007; Castree 2008; Brockington and Duffy 2010). Indeed, a focus on capital accumulation in many ways defines critical accounts. Smith (2007) argues directly that nature is becoming an "accumulation strategy." Harvey (1996: 174) writes that new ecological commodities are at their root manifestations of "rational environmental management and resource allocation for capital accumulation." Brockington and Duffy (2010: 470) reiterate that through green politics, new enclosures, and green enterprises, "conservation fuels processes of capital accumulation." Foster et al. (2009: 1090) argue that "putting price tags on species and ecosystems will only serve.... to subsume nature to the endless growth of production and profits." Büscher et al. (2012: 7) are emphatic that "environmental (and other) crises increasingly are themselves opportunities for capitalist expansion" (emphasis original).

These Marxian-inspired approaches provide an important counterweight to the reformist optimism of ecological modernization theories, and are no doubt partly correct: new markets in "neoliberal nature" (Bakker 2005) do create new opportunities for accumulating wealth. The global trade in habitat offsets, mostly in the United States, is valued at roughly $\$ 3$ billion dollars (Ecosystem Marketplace 2011), while the global carbon market topped $\$ 30$ billion in 2014 (World Bank 2014). These sums remain somewhat trivial relative to a gross world product moving towards $\$ 100$ trillion, but as champions of "ecosystem markets" are quick to argue, opportunities to profit from environmental protection will likely grow, and are nonetheless already enough to get the cogs of capitalism turning.

Understanding these market-oriented modes of environmental protection primarily as outcomes of green entrepreneurship or capitalist commodification can be misleading, however. Species conservation banks in the United States, for example, have not simply emerged in areas where more endangered species habitat is encroached upon by land development - that is, in areas were there would be more profitable opportunities to sell things like endangered species offset credits. California, the epicenter of American species conservation banking, does have the highest absolute number of officially listed threatened and endangered animal species, and, as the most populous state, has experienced high levels of land development in the past several decades.

\section{[Figure 3 about here]}

But mapping these species-land development overlaps reveals that several states in addition to California, most notably Florida, also have ecological-economic conditions that might support the development of species conservation banking, and thus yield ripe opportunities for accumulation. Figure 3 plots these overlaps over time using what I abbreviate as species listing expected values (SLEVs). This metric uses county-level U.S. Fish and Wildlife-defined endangered species ranges and county-level U.S. Census-based population growth estimates, 
which are a very strong proxy for land development, ${ }^{6}$ to estimate the overlap of endangered species habitat and the use of land for building projects. I calculated SLEV for each of the 1,127 state-years for 49 states $^{7}$ between 1990 and 2012 (mean values in table A3). As expected, states with very low SLEVs - that is, little endangered species-land development overlap - typically have no species conservation banks, while states with moderate to high SLEVs may have some species conservation banks. But many of the states with the highest SLEVs, like Florida, Georgia, and Alabama, have few or no species conservation banks at all (figure 4). Endangered species-land development overlaps, and thus 'raw' opportunities for accumulation and 'greening' the land development economy, poorly predict where this particular example of command-andcommodify regulation has emerged.

\section{[Figure 4 about here]}

This finding unto itself points to the need for a more nuanced accounting of the emergence species conservation banking, one that goes well beyond theorizing how either well-intended or nefarious capitalists seek to integrate nature into markets. Indeed, even the simple fact that species conservation banks are concentrated in California - a state home to a storied and influential environmental movement (Gottlieb 2005; Sine and Lee 2009) and with environmental regulations that may look more European than American (Vogel 2012) - suggests that the rise of these institutions is coupled to far more than just profit-seeking or even green-minded entrepreneurialism. Stringent environmental rules, environmental groups, and California's general environmental exceptionalism are instead signaled by the data, and at the very least must intersect with the environmental-economic explanations highlighted by existing social scientific accounts.

Fully theorizing new state-directed but market-oriented modes of regulation, like species conservation banking, thus requires moving beyond theories of accumulation or of 'greening' the economy. It also requires identifying what, exactly, makes these institutions unique as modes of regulation - modes that seem empirically to have an affinity with strong environmental rules and environmental movements. This institutional specificity, I argue, has to do with the particular ways that institutions like species conservation banking wield power - that is, how they coerce actors into doing things that they might not otherwise do.

\section{Power in two dimensions}

It is a truism in sociology that power can be exercised in multiple ways, but Weber (1978: 943) usefully suggests that two of these ways can be thought of as "diametrically contrasting," or what I will consider as orthogonal. In one dimension, ${ }^{8}$ institutions can wield power by what Weber (1978: ibid) calls "domination by virtue of authority, i.e. power to command and duty to

\footnotetext{
${ }^{6}$ County-level data on land-use change or economic output in construction, which drives demand for ecological mitigation, is not widely available. At the state level, economic output in the construction industry is robustly correlated with foregoing increases in population, suggesting that county-level population growth is a strong proxy for land development also at that scale. See table A2.

${ }^{7}$ Alaska was excluded because of inconsistencies in population data.

${ }^{8}$ To reiterate, like Weber, I do not claim that the dimensions I identify are the only dimensions that power can be exercised along - just that they are two dimensions that are useful for distinguishing between different modes of structuring economic action.
} 
obey." This is "patriarchal, magisterial, or princely power" (ibid), visible in all instances wherein some authority issues a command, edict, or law, and where, "the authority which is claimed... is actually heeded" (ibid: 948). Concern here is not with the precise and largely unknowable motivations for such obedience, which can range from fear of sanction (i.e. instrumental rationality) to habituation to hegemony. Focus is rather on the qualitative mode of domination: power in this form is exerted by virtue of the fact that a command is issued - most often by the state - and followed as such. Sanctions may play an important role in authoritative power; threats of criminal prosecution, financial penalties, violence, or social exclusion often accompany authoritative commands. But a threat of sanction does not define authoritative power as such. It is defined instead by the direct, one-to-one correspondence between an authoritative command issued and command received: Do X, period. (The ominous "or else" is not strictly necessary.)

But as economic sociologists have regularly pointed out, power can also work in a second and orthogonal dimension, vis-à-vis what Roy (1997: 13-16) calls structural power (see also Swedberg 2005: 233) and what Weber succinctly defines as "domination by virtue of a constellation of interests" (ibid: 943). The "purest type" of this form of power, Weber suggests, "is monopolistic domination in the market," wherein power is exerted not by any direct commands at all, but where "the conduct of the dominated, who remain... formally free, [is] motivated simply by the pursuit of their own self interests" (ibid). This sort of economic power is analytically distinct from the authoritative power discussed above. No direct commands are issued; no formal sanctions are threatened. Instead, the will of one is imposed by structuring and constraining the set of choices available to another, such that out of a wide ranging field of hypothetically possible actions, only a handful of limited possibilities 'make sense' to the dominated person or group. Thus, options A, B, C, and D may all be technically feasible and freely allowed, but only B may be 'rational' given the context that a particular decision is made within - say, in a specific political environment or within a particular property rights regime. Unlike direct authoritative power, economic power is thus indirect: it structures action by altering the economic context that the action unfolds within. In contemporary capitalist economies, this context is very often 'the market,' where the politically and culturally conditioned terms of the "the competitive price struggle" (ibid: 82) shapes and constrains economic behavior, but where authoritative commands do not compel "formally free" actors to do one thing and not another (Fligstein 2001; Fligstein and Dauter 2007; Fourcade and Healy 2007). ${ }^{9}$

These two orthogonal modes of domination suggest a neat four-fold typology of regulatory power: institutions can structure economic action with high levels of authoritative power and low levels of economic power; low levels of authoritative power and high levels of economic power;

\footnotetext{
${ }^{9}$ Skeptics of the distinction between authoritative and economic power will argue that these two forms of power are not so different, insomuch as compliance with an authoritative command may be conditioned on an assessment of the costs and benefits of compliance, just as making a "free choice" in a market is conditioned by the structural context that the decision is made within - that is, by considering the costs and benefits of taking one action rather than another (see e.g. Hale 1935). This is true, but exactly misses the point of Weber's analytical distinction: that similar ends-economic action of a particular sort - can be achieved by qualitatively different means, that is, by using different modes of domination. One can ask, for example, how and to what extent collapsing the coercion experienced by the serf into the same category as the coercion experienced by the wage laborer offers insight for understanding the distinctive economic institutions that each are embedded within.
} 
high levels of authoritative and high levels of economic power; or low levels of both forms of power. Each of the four distinct power configurations, in turn, can be named, and maps cleanly onto ideal-typical examples of regulatory institutions, some of which are already well known (figure 5).

\section{[Figure 5 about here]}

So-called (and often politically derided) command-and-control institutions are those that regulate economic action with high degrees of authoritative power but comparatively less economic power. Classic environmental and industrial regulations often take this form, with states issuing direct commands that production and manufacturing processes meet particular standards in order to promote worker safety, environmental protection, and so on (Sinclair 1997). Indirect structural incentives to take particular actions - that is, forms of economic power — play a secondary role in these institutions, only becoming important is so much as they stand in relation to direct commands issued in the first place. Fines and penalties for noncompliance, for example, do inject a certain economic calculus into command-and-control institutions, but the mode of domination is still authoritative: power is wielded through direct mandates - not primarily with structural-contextual incentives that only indirectly 'coerce' actors into making particular decisions.

More recently discussed private regulation, by contrast, wields power in the opposite configuration, with low levels of authoritative power but high levels of economic power. Voluntary product labeling and certification schemes often associated with neoliberalism, such a "sweat free" apparel, "fair trade" food products, and "sustainably harvested" lumber are clear and well-theorized examples of private regulation (Bartley 2007; Guthman 2007; Vogel 2008; Kinderman 2011; Besky 2013; Locke 2013). These institutions indirectly 'coerce' actors —often firms - into complying with particular standards or practices not by issuing direct authoritative commands and threatening penalties, but because a "market for virtue" (Vogel 2005) and the moral status of particular exchanges (Fourcade and Healy 2007) creates indirect, structuralcontextual incentives for compliance, including reputational and status benefits for firms, higher profit margins, and the possibility of staving off more authoritative forms of state-led regulation (Walker and Rea 2014; Kaplan 2015). It is important to note that private regulatory institutions are not uniquely permeated by cultural and morality; authoritative limits on economic activity imposed in command-and-control institutions are also founded on moral and cultural arguments about 'appropriate' forms of economic action. What distinguishes private regulation is instead the way it relies primarily on economic power to structure economic action, reshaping the dynamics of exchange in markets by reconfiguring structural-contextual incentives without deploying direct, authoritative commands.

But institutionalized modes of domination need not only deploy either high levels of authoritative power or high levels of economic power. The 'voluntary' or 'unregulated' institutions in the lower-left corner of figure 5 include modes of structuring social action by means largely outside of both authoritative commands and broadly economic incentives - that is, with low levels of both authoritative and economic power. I set this class of institutions aside for now; however important and rich they may be as objects of study, just like command-and-control and private forms of regulation, these forms of regulation (or non-regulation) are not the explicit focus of this article. 
In the upper-right of figure 5, however, are command-and-commodify institutions, like species conservation banking, cap-and-trade, and mandatory insurance markets. Like commandand-control institutions, command-and-commodify institutions rely heavily on direct, authoritative commands to shape economic action. In mandatory carbon emissions markets, habitat offsetting schemes, and compulsory insurance markets, for example, actors are authoritatively forced by the state to purchase emissions credits, species credits, or insurance products, and sanctions are threatened for violators. But these commands do not compel any specific action beyond entrance into a market for a particular commodity - usually an entitlement to perform an action (e.g. to emit carbon dioxide) or to receive a service (e.g. compensation for damages or healthcare costs). Once actors are 'in' the market for such entitlements, authoritative commands effectively become a secondary means of structuring social action. Instead, the structurally and culturally contingent dynamics of market exchange 'take over' as the primary source of social power, incentivizing some actions over others without directly prescribing any particular activity. A carbon emitter may thus elect to reduce emissions to avoid the cost associated with buying emissions credits - and she may make these reductions however she likes - or she may simply pay for emissions credits to continue emitting at standard or even elevated levels. The important point is that social and especially economic action in such command-and-commodify institutions is shaped by using high levels of authoritative power to compel actors to enter a specific, usually state-fabricated market (Vogel 2016), and simultaneously relying on economic power within that market to then incentivize particular actions over others absent specific commands. This particular power configuration is what sets command-and-commodify institutions like species conservation banking apart from other modes of regulation, like command-and-control and private regulatory institutions. Figure 6 summarizes these differences.

\section{[Figure 6 about here]}

\section{Explaining institutional emergence}

The command-and-commodify framework offers a useful way of understanding how statedirected but market-oriented institutions work. But by focusing on configurations of regulatory power, this approach also reorients towards a different and prior question: what are the conditions under which both authoritative and economic regulatory power expand together, such that command-and-commodify institutions develop rather than other regulatory forms, like private or command-and-control institutions? To answer this question I return first to the case of species conservation banking in particular, before generalizing from the case to offer a more generic and transportable theory of the emergence of command-and-commodify regulation.

\section{Shifts in authoritative power}

It is important to remember that the legal legitimacy for species conservation banking stems centrally from federal law, and in particular the federal Endangered Species Act. As will become clear below, state law also matters considerably for understanding the emergence of this institution, but even so, most species conservation banks sell species credits that satisfy requirements for offsetting that are imposed by federal environmental regulators. These are environmental bureaucrats working in regional and field offices around the United States, but who are direct employees of the executive branch of the federal government, and who are ultimately accountable to their bosses in Washington D.C. Policies and practices related to state 
laws are not the direct concern of these regulators; indeed, divisions between state and federal agencies are often stark and can be fraught with tension and disagreements. With this in mind, a basic empirical question becomes, how did federal regulators in California, in principle beholden to the same law and policy as their colleagues in other states, expand their authoritative power in way that allowed them to begin demanding that land developers provide endangered species habitat offsets, while federal regulators in other states were mostly not able to do so?

Any clear answer must begin with the basic administration of the Endangered Species Act. In all states, federal regulators agree that the national Endangered Species Act mandates that the U.S. Fish and Wildlife Service or National Marine Fisheries Service (hereafter, the Services) review land development plans when a proposed project overlaps with the habitat of an officially listed endangered species. If the Services determine that the project will contribute to the extinction of a protected species, they can issue an official decision called a "jeopardy determination" that could effectively stop the project, usually by requiring major and often costprohibitive modifications to the project plan. Or, if the Services determine that the project will not 'appreciably reduce the likelihood of survival and recovery,' they approve the project, which can then move ahead as planned.

In many cases, however, the Services take a middle ground, issuing an official "biological opinion" that requires developers to modify projects in relatively minor ways in order to first "avoid" and then "minimize" harm to endangered species. One way to further reduce overall harm is through "compensatory mitigation." 10 As with the general project review process described above, it is also widely accepted that if a project is reviewed under a particular section of the Endangered Species Act - Section 10 - these compensatory mitigation requirements may be enforced as part of a "habitat conservation plan" for the relevant species. Under Section 10, in short, federal regulators can require ecological offsets. That is uncontroversial.

Many projects, however, are reviewed under a different section of the law-Section 7which does not explicitly allow compensatory mitigation. ${ }^{11}$ Indeed, the Section 7 consultation handbook, which is not formal law, but which "provides internal guidance and establishes national policy" for federal environmental regulators, seems to be quite clear on this point:

${ }^{10}$ Two notes are important here. First, mitigation is only formally allowed after (and never instead of) taking steps to first avoid and then minimize ecological harm, although distinctions within this hierarchy are clearly subjective (Andrus 1981). Second, "mitigation" or "compensatory mitigation" are the terms used in American environmental policy for the more general concept of "offsetting" as already defined in this article. Readers should thus understand the terms "mitigation" and "offset" as synonymous in this article.

${ }^{11}$ In brief, Section 10 obtains when any non-federal entity (e.g. a private citizen or state government) seeks project approval. Section 7 obtains when a project involves a "federal nexus" (e.g. another federal agency or federal funding). Three things make Section 7 consultations considerably more likely than Section 10 consultations: 1) Compliance with Section 10 is comparatively easy to avoid. In the absence of compulsion to consult with the Services, a private land developer may elect to "shoot, shovel, and shutup" (Salzman 2005: 916) rather than obey the law. 2) Developing a habitat conservation plan under Section 10 is generally arduous, creating incentives to return to (1) above, or to consult under Section 7, if possible. 3) A federal nexus is actually quite common. For example, all projects that impact "waters of the United States," must obtain a permit from the U.S. Army Corps of Engineers to comply with the Clean Water Act. This creates a federal nexus. 
Section 7 requires minimization of the level of take. ${ }^{12}$ It is not appropriate to require mitigation for the impacts of incidental take (emphasis added) (U.S. Fish and Wildlife Service and National Marine Fisheries Service 1998: 4-53).

This, as a federal regulator in Washington State explained, created

...a regulatory problem in that there are people in both Services that question our ability to ask for mitigation under Section 7.... There is a school of thought... that says... in a nonjeopardy biological opinion we couldn't write terms and conditions that directed people to [mitigate] (12/23/14).

An informant in Mississippi agreed: "We're not allowed to really require mitigation... our goal is to minimize the level of [harm]" (12/12/14). Speaking in hypothetical terms, an Alabama regulator drove home the point:

Under Section 10, I think, we have a little bit more leverage.... Under Section 7... [an applicant] could balk [at a request for mitigation] and say, 'No, we just have one animal here - we're going to kill it and we're going to make you [the Services] say jeopardy or non-jeopardy.' And technically we have to go along with that because of not necessarily requiring mitigation for species impacts... (12/22/14).

Apart from the limits imposed by this reading of the federal law, in most states, flimsy statelevel laws also did not help federal regulators make increased demands for habitat offsets. As one informant explained,

When you come into the southeast, our states [Georgia, Mississippi, Alabama] have very weak protections of state species. They really let us [federal regulators] do all the work $(12 / 12 / 14)$.

Even in 'greener' states like Oregon, state laws may not have been conducive to expanding authoritative regulatory power as would be required for federal regulators to demand endangered species offsets. As one informant there put it, "the [state habitat] policy just doesn't have teeth" $(2 / 1 / 12)$.

In regulatory contexts like these, land developers were accustomed to not having to provide compensatory mitigation for impacts to endangered species. These less stringent norms, in turn, made it even more difficult for federal regulators to stiffen their regulatory demands. An informant based in Oregon explained:

Let's say it's the same biologist who's been with [the Services] for 20 years... You may still be dealing with some of the same federal agencies and developers that are coming to

12 "Take" is the legal term used in the Endangered Species Act to designate what in colloquial terms would be harm or a disturbance to a protected species and its habitat. 
you for permits, and all of a sudden you're kind of changing the game. You know they're going to ask what's changed. 'Before I could just put something in place. Now you're saying I have to go buy land somewhere [i.e., provide offsets] (8/15/12)?'

Even informants in California were aware of the conflicts and resistance such regulatory shifts could cause. Asked why federal regulators in other states do not impose mitigation requirements under Section 7, one California informant speculated,

The politically correct answer is, other regions are still developing their policies and perspectives on this... The less politically correct reason is, because it would create such an uproar, I think, with developers... (3/21/12).

In California, however, things unfolded differently. There, strong state-level environmental laws, namely the California Environmental Quality Act (CEQA), included relatively stringent habitat offsetting requirements. Again, it is important to recall that in a federal governmental system such as that of the United States, federal regulations are largely independent from such state-level laws; a state-level mandate for "compensatory mitigation" does not provide federal environmental regulators with any formal-legal authority to make parallel regulatory demands.

Nonetheless, researchers have shown that legitimacy conferred on a means of regulatory compliance - for example, purchasing a species credit to satisfy a regulatory demand for offsets - is often conditioned on initial organizational responses to regulation in the first place (Edelman et al. 1999). Thus, in a place like California, developer compliance with state-level offsetting requirements may have provided a template for federal regulators to make parallel demands - even if federal regulators lacked the formal authority to do so. Land developers, in turn, may have acquiesced to such demands as a means of "symbolic compliance" in order to avoid project-delaying regulatory hang-ups in the federal bureaucracy (Edelman 1992). One informant made this point almost exactly:

We do it [mitigation] because we do it under CEQA, and we do it under the state Endangered Species Act. So the feds [the Services] come along and just piggyback on that, and we've been doing it for 20 years, so even though the feds don't have a legal authority to ask for it, most people think they do. [...] [T] here's just a mindset that everybody mitigates for their impacts no matter what (3/14/12; emphasis added).

Once again, however, effects from state law alone have clear explanatory limits. In purely empirical terms, offsetting requirements imposed by state regulators under the California Environmental Quality Act may or may not correspond to federal demands for offsets that Service regulators make. In some cases, the amount of offsetting demanded by federal regulators far outstrips state-level demands, ${ }^{13}$ suggesting that federal regulators in California are drawing on independent sources of authority that extend beyond just 'piggybacking' on state law. Perhaps even more importantly, California is not alone in having state-level laws that make strong demands for land developers to offset damage to endangered spices and their habitat. In

\footnotetext{
${ }^{13}$ See for example Association of Irritated Residents v. County of Madera (2003) 107 Cal.App.4th
} 1383 
Washington State, for example, a state law in place since 1971 authorizes state regulators to require offsets for "significant adverse environmental impacts," which are in part determined through the presence of endangered species (Washington State 1971). This is not at all unlike the requirements of the California Environmental Quality Act. But as of 2014, Washington State had yet to approve a single species conservation bank, and as the informant from Washington State quoted above reveals, federal regulators there remain mired in debates about whether they even have the authority to ask for compensatory mitigation under Section 7 of the national Endangered Species Act.

So what, other than supportive state laws, allowed federal environmental regulators in California to demand endangered spices offsets? The answer turns out to be geographically specific, even within the state. Somewhat ironically, in southern California, agreement that offsets could be required under federal law looped back once more to the influence of state statutes. In the early 1990s in San Diego and Orange Counties, land developers looking for ways to move ahead with large-scale development plans, state-level environmental regulators, and environmentalists concerned about the negative impacts of such land development, began to develop some of the first large-scale, regional habitat conservation plans (cf. Feldman and Jonas 2000). Recall that habitat conservation plans are created under Section 10 of the national Endangered Species Act, which unambiguously allows federal regulators to require offsets.

But it was a suite of strong state-level environmental laws, notably the Natural Community Conservation Planning Act, the California Endangered Species Act, and again, the California Environmental Quality Act, that drove the planning of these habitat conservation plans (Carroll et al. 2009). Thus, under the newly developed habitat conservation plans - again, formed in large part via state-planning processes, but in consultation with federal regulators - if land developers wanted to build, they would also have to provide endangered species offsets.

But the politics of expanding authoritative power unfolded differently in northern California. There, institutional support for imposing requirements for offsetting stemmed from subtler but more profound shifts in regulatory practice. In northern California, Service regulators did not rely on state law or Section 10 of national Endangered Species Act to legitimate offsetting requirements. Instead, also in the 1990s, these federal regulators began to make more fundamental ecological arguments. They argued that development projects that only "avoided" and "minimized" negative impacts to endangered species under Section 7 (not just Section 10), and that individually posed a minimal threat to species recovery, were nonetheless collectively pushing species towards extinction via a slow "death by a thousand cuts"-a cliché that many informants invoked. As one former regulator put it, "avoid, minimize, then you have this residual. They're slowly eating the resource [the speices]" (3/22/12). From this ecological perspective, as another regulator explained, land developers,

...have to make an argument that they're not appreciably reducing the likelihood of survival and recovery, or I should be writing a jeopardy opinion" (3/23/12).

Such a decision could be the death knell of a land development project. But, the same regulator continued, when a developer offers to provide compensatory mitigation, or

...when they add, 'Well, we're gonna buy credits at a [species conservation] bank,' it starts to make conservation sense because [...] you're providing for the long-term viability of the species $(3 / 23 / 12)$. 
Offsetting was thus not technically mandated, but including provisions for endangered species offsets became a de facto requirement if land developers wanted to avoid a project-halting jeopardy determination.

Expanding authoritative power in order to impose these new requirements, however, directly conflicted with national policy, and thus required both careful legal maneuvering and political support. Regulators wiggled around legal-linguistic barriers by relabeling "mitigation" as "conservation," since requiring "conservation measures" is allowed under Section 7. When asked how this works, a conservation banker was blunt:

Informant: Well, you've gotta work in a field office that has the cojones to require it [mitigation], to be frank, and there's not very many out there at a federal level. ...but in [California] they do write biological opinions that require conservation measures. They don't call it mitigation.

Author: I see, 'cause that's a legal issue, right?

Informant: Yeah. It's all wording. But it's compensation for the loss such that they can come to a non-jeopardy opinion.

Author: I see. So it's sort of some finesse of language-

Informant: They have to have the will to make people mitigate. That regulator has to. And in this [...] region and some other regions of the Fish and Wildlife Service they do, and they make people mitigate. And others...

Author: Don't?

Informant: They don't because for whatever political reason they get enough heat that they don't feel like they can mitigate $(3 / 21 / 12)$.

Regulators in California were not immune to this kind of political "heat"; land developers there, like anywhere else, were not eager to have to provide costly offsets for impacts to endangered species. As one informant put it, "First, the developers are [asking], 'Why the hell are you regulating me in the first place?"' (3/22/12). But state-level political appointees in a Republican governor's administration, along with would-be conservation bankers, strongly supported these ecologically-justified expansions of authoritative power. This support gave federal regulators in California the political back-up necessary to overcome resistance by land developers. Understanding how and why requires shifting discussion from the expansion of authoritative power, to the coupled expansion of economic power that is also required for command-and-commodify regulation to emerge.

\section{Shifts in economic power}

As made clear above, in most states authoritative expansions of regulatory power were inhibited by conventional interpretations of the Endangered Species Act. Still, I did find some evidence that federal regulators outside California used economic power to encourage land developers to offset impacts to endangered species. As one regulator explained,

I may tell someone, 'Yes, you need to buy credits at a bank in order to offset impacts.' And they may say, 'Well I don't want to do that.' And then it could be, 'Well, then you need to do two years of survey on your property for the species in question.' Well, the land owner 
doesn't want to spend two years waiting to see what species he has on his property, so often times, they'll just go ahead and volunteer to buy credits at a bank $(12 / 12 / 14)$.

Efforts to create incentives for offsetting in these kinds of ways, however, were often undermined. A Florida statute adopted in 2012, for example, prohibits counties from requiring, "as a condition of processing or issuing a development permit that an applicant obtain a permit or approval from any state or federal agency...". 14 This means that local (county-level) authorities cannot deny building permits even if a developer has not even interacted with federal regulators. In such a context, as one informant speculated, land developers are apt to ask, "Well, what's the risk that even if I cause take, that anybody is gonna know to do anything about it?" $(12 / 22 / 14)$. The not-so-subtle implication is that it may be more appealing for land developers to not comply with the Endangered Species Act than it is to try to gain federal regulatory approval, which could include having to provide offsets.

Sometimes federal regulatory practice itself undercut the ability of federal regulators to encourage offsetting. As one informant in the South rhetorically asked,

What if I want to follow different standards that are less stringent? I think sometimes in the Southeast we want to give [people] multiple ways to handle their endangered species issues. I'm not saying that's a good thing-it just is what it is $(12 / 12 / 14)$.

Whatever the normative status of this regulatory approach, its flexibility made alternative negotiations possible for land developers, making it difficult for regulators to consistently create economic or structural incentives for offsetting.

But of course government regulators are not the only actors who can wield economic power to make offsetting 'make sense' for land developers. Social movement activism may also push actors and organizations towards adopting new or alternative forms of economic action (Rao et al. 2000; Bartley 2007; King and Pearce 2010). What is more, specific laws and policies, like the Endangered Species Act, are likely to act as targets for mobilization that activists can use to challenge status quo administrative and regulatory practices (Campbell 2003; Walker et al. 2008). Thus, where regulators themselves fail to authoritatively impose offsetting requirements, advocacy groups can bring suit, demanding stronger enforcement of environmental laws. In some instances such suits might shift the authoritative power of the law itself, for example, by creating precedents that fundamentally change the rules of the game. In most cases, however, this legal activism is better understood as a form of economic power: formal authoritative rules change little if at all, but the risk of facing a lawsuit and the cost of settling out of court shift the terms of exchange in the land development market, and change how land developers approach the decision to provide habitat offsets. In essence, it may simply be cheaper to buy offsets than to fight a legal battle over having to provide them.

To assess the ways that legal activism may have had such effects, I used a LexisNexis Academic search to assemble a set of 313 state-based court cases that contained the terms "ESA" (Endangered Species Act), "biological opinion," and "mitigation." Each case was coded by

\footnotetext{
${ }^{14}$ See Florida statues section 125.022, available at http://leg.state.fl.us/Statutes/index.cfm.
} 
geographic origin, argument date, primary species at issue, basic interest groups in conflict, and the outcome of the case. ${ }^{15}$

The results show that in the time span considered, from 1985 to 2012 , fully $79 \%$ of litigation was targeted at regulators and brought by environmental advocacy organizations. The vast majority of Endangered Species Act-related litigation was thus not initiated by developers pushing for regulatory leniency, but by environmental groups demanding stronger enforcement of environmental laws. But in most states this legal pressure was weak. The median number of cases in any given state was zero. Oregon was among the states with the highest levels of overall litigation, but still only saw 37 cases (about $12 \%$ of the national total) during the 27 years considered. 29 of these (78\%) were focused narrowly on salmonids, giving regulators less legal backup for strengthening Endangered Species Act enforcement for other species. The same was true in Washington, with 33 cases (11\% of national), 25 (76\%) of which focused on salmonids. In Florida there were only 17 cases (about $5 \%$ of the national total), or only slightly above one case every two years. Remarkably, nearly all the states with high levels of overlap between land development and endangered species ranges (i.e. with high SLEVs, as discussed above) are also states with very low levels of legal contention centered on the Endangered Species Act (table 1). These low levels of Endangered Species Act-related litigation, in turn, meant that land developers in those states did not face significant threats of suit if they failed to provide highquality habitat offsets in order to help compensate for loses of endangered species habitat. This meant there was much less - if any_need for species conservation banks in those places.

\section{[Table 1 about here]}

But once again, things unfolded differently in California. There, legal pressure brought by environmental groups was far greater. Overall, 93 (30\%) of the court cases I coded originated in California - far more than anywhere else, and at levels that have been sustained through time (figure 7). Explaining this heavy concentration of environmental litigation in California is beyond the scope of this article. Critical for this analysis is simply noting the ways these legal challenges reconfigured the economic calculus of providing habitat offsets. As one informant put it,

...it all comes down to time and money. [...] ...the attorneys would fight, and the people who felt it [offsetting] was wrong would fight. The financial guys would go, 'Oh, wait a minute, if I delay this project for two years, I've already invested 100 million'_-cause that's usually what you're talking about [for a] big development. 'I have a carrying cost of 10\% interest. That's 10 million dollars a year. If I wait two years to fight this - and I might win in two years - that's 20 million dollars that I've lost. [But] if I can do this [offset], create some habitat, and it cost me 10 million dollars, I'm in the black 10 million dollars' $(3 / 23 / 12)$.

${ }^{15} \mathrm{~N}=289$ unique cases. However, several cases were coded in multiple states when conflicts spanned borders (e.g. litigation over salmon runs in border rivers), yielding 313 state-based cases. Terms were chosen to focus specifically on federal law because it applies to all states, and because suits often focus on the official biological opinions that Service regulators write, including provisions (or the lack thereof) for mitigation. Outcome categories were in favor of: NGOs; regulators; industry; state; city; landowner; tribes; and military. Search includes all federal district and appellate as well as state appellate cases. 
In such a litigious context, then, it began to 'make sense' for land developers to include compensatory mitigation in project plans - even when not formally required to do so.

\section{[Figure 7 about here]}

But it was the politics of land development and environmental regulation in California in the mid-1990s that pushed the process of institution building firmly in a market-oriented direction. At that historical moment, fierce political-environmental battles over logging, spotted owls, and the Endangered Species Act loomed over politicians, particularly in the West (Widick 2009). Confronted with growing demands for higher quality ecological offsets, but also with strong political support from land developers, the Republican governor's administration in California actively sought institutional settlements to problems of environmental regulation. As one appointee recalled,

The governor, in effect, said to me, 'Find a way to solve this problem...' [...] ...development has stymied. The environmentalists were suing continuously, and at the same time we were not accomplishing an optimal degree of conservation (3/27/12).

In this political context, it was clear enough that more stringent requirements for protecting endangered species habitat, including offsets, would help appease environmentalists and concerned regulators. But, advocates argued, if third parties were allowed to preserve land and then effectively sell units of pre-created mitigation (species credits), land developers and environmental groups might both find reason to celebrate. Informants emphasized three points related to this argument.

First, if such an approach were adopted, small "postage-stamp"-sized mitigation parcels with questionable ecological value could be effectively amalgamated into larger tracts of conserved land more likely, it was argued, to effectively support populations of endangered species. 'Credits' could then be slowly 'debited' from these 'banks' of species habitat as needed to satisfy offsetting requirements. Even environmental groups wary that species conservation banking might promote development, by making it easier to gain regulatory approval, were taken in by this argument. As one informant recalled,

So they all [environmental groups] came in and started bouncing all over me because, 'All you're doing is allowing development with these banks.' [...] I said, 'I'll take you out here and show you vernal pools that are locked up inside a whole housing development and have no [ecological] value whatsoever.' They got it right away. (3/22/12)

But environmental groups were at least partly right: land developers did stand to benefit from allowing third parties to provide offsets via species conservation banks. Hence the second and third arguments in favor of this regulatory approach: from a land developer's point of view, 'it's just easy to buy a credit, and that time saves money" (3/22/12). And perhaps even more importantly, a species credit is "something that you can exchange to extinguish liability" $(3 / 16 / 12)$. If a land developer is forced to provide her own compensatory offset, she is legally culpable for that offset site - the land - in perpetuity. But if she purchases a species credit, liability for ensuring the perpetual preservation of that land is transferred to the species 
conservation banker, with obvious legal, practical, and accounting benefits for the land developer.

Together, these three arguments acted as a powerful set of incentives working against land development 'as usual.' Importantly, none formally compelled land developers to change their land development practices; this was not a case of authoritative commands structuring economic action. But all three factors effectively constrained the choices land developers could 'rationally' make. Embracing larger-scale conservation in the form of 'banks' appeased regulators and environmentalists by creating more ecologically robust conservation sites. This, in turn, reduced the likelihood of a lawsuit and eased the regulatory approval process. Purchasing species credits was also easier than creating one's own offsetting site. Perhaps most importantly, buying species credits absolved land developers of responsibility for maintaining mitigation land. By creating a "constellation of interests" that favored species conservation banking, state-level administrators and environmentalists effectively, if indirectly, expanded economic regulatory power in ways that reconstructed the land development market. With the help of the shifts in authoritative power already described, this paved the way for the emergence of a new form of command-andcommodify regulation.

\section{Reconstructing markets; rethinking regulation}

I have so far argued that many state-directed but market-oriented forms of regulation, like capand-trade or habitat offsetting schemes, are in fact specific instantiations of a more general institutional form that can be usefully called command-and-commodify regulation. I have further shown how institutions of this sort are distinctive in terms of the ways they hybridize authoritative and economic forms of power. And in the foregoing empirical discussion, I have used this framework to help explain how and why one example of command-and-commodify regulation - species conservation banking-flourished in California, while it floundered in other American states. The question that remains is, what general social processes can be abstracted from this particular case in order to help explain the emergence of other examples of commandand-commodify regulation, and processes of regulatory change more broadly?

A fruitful answer begins with the concept of market reconstruction - that is, by focusing on the ways social conflicts and broadly political struggles reshape and reconstruct established systems of exchange in markets. The foundation of this approach draws on the insights of legal realist scholars writing in the 1920s, 30s, and 40s (Klare 1988; Block 2013). Of course these scholars were not concerned with environmental regulation per se-the modern environmental movement and institutionalization of environmental protection had yet to begin (cf. Frank et al. 2000). But like Weber and Marx before, legal realists highlighted the ways that power is wielded not only through authoritative commands, but through markets, and more precisely through legally codified market-supportive institutions, most especially property rights regimes and contracts, which work as indirect forms of economic coercion (Hale 1935; see also Campbell and Lindberg 1990; Roy 1997). The market reconstruction perspective thus redirects attention from the politics of creating and (re)regulating markets as such, to the politics of institutionalizing and (re)configuring systems of authoritative and economic power so as to structure economic action in particular ways (Hale 1935, 1943).

Three-quarters of century later, economic sociologists have highlighted many of the same points. "Property," as Roy (1997: 16) summarizes, "institutionalizes power," and of course a central insight of the sociology of markets is that these institutions are anything but autonomous or "free" of political and state intervention (Campbell and Lindberg 1990; Fligstein 2001; 
Polanyi 2001; Carruthers and Ariovich 2004; Vogel 2016). Indeed, contemporary sociologists have in many ways gone well beyond the legal realist critique, highlighting the ways that markets and exchange are not only social and political creations of the law and thus of states, but are culturally contingent (Fourcade and Healy 2007; Quinn 2008; Zelizer 2011) and continuously shaped by contention, mobilization, and 'power plays' within them (Rao et al. 2000; King and Pearce 2010; Rao et al. 2011).

But by specifically shifting focus to the ways that power, both authoritative and economic, shapes economic action, a market reconstruction approach provides a particularly clear framework for mapping out the ways that contentious politics reshapes markets and reconfigures modes of regulation. Figure 8 summarizes the discussion below.

\section{[Figure 8 about here]}

In one dimension, a market reconstruction approach helps make clear how, by shifting the composition of a market's 'moral saturation,' (Fourcade and Healy 2007: 300), changing the costs of doing business (Weber et al. 2009; Ingram et al. 2010), or remaking or strategically altering the legal context that exchanges occur within (Hale 1943; Rao et al. 2011), actors and activists are in fact wielding economic power that can indirectly coerce market participants into acting in particular ways. The social mechanisms that reconfigure economic power along these lines can be thought of as exchange deterrents, so named for the ways that they do not firmly prohibit, but instead create indirect disincentives (deterrents) for taking particular actions in a specific market. Thus, for example, by making the logging of old growth timber both physically challenging and morally questionable, forest activists are not just delegitimizing a product or addressing a market failure (cf. Rao et al. 2000). More basically, they are using exchange deterrents to restructure economic power such that, even absent authoritative state commands, it may begin to 'make more sense' for a timber company to harvest regrowth, and perhaps even participate in a sustainable forestry certification scheme (Bartley 2007; Widick 2009). The same can be said of the environmental suits in California that made it 'rational' for land developers to buy species credits in order to help avoid costly litigation, or of the legal advocacy that ensured that liability for compensatory mitigation was transferred from land developers to species bank owners when purchasing species credits. These specific exchange deterrents reconfigured and, more precisely, expanded economic regulatory power in California, and thus, even if unwittingly, constrained the 'rational' courses of action builders could take in the state's land development market. This, in turn, set the stage for creating a market in endangered species credits.

In a second dimension, however, a market reconstruction approach demands equal attention to the ways that direct, usually state-imposed commands can also restructure the terms of exchange in a market, but this time by shifting configurations of authoritative power. Examples include specific prescriptions for action outlined in administrative rules, including legal precedent (Schneiberg and Bartley 2001; Quinn 2008); the passage or dissolution of laws constraining particular exchanges (Vogel 2012; Funk and Hirschman 2014); and even the direct use of state-sponsored physical coercion and violence to force actors to take particular actions, or to make space for particular markets (Levien 2013). As in the case of economic power discussed above, movements, mobilization, and contention, including political battles over the morality and cultural embeddedness of particular market exchanges (e.g. Zelizer 1978; Andrews and Seguin 2015), drive these shifts in authoritative power. 
But unlike the exchange deterrents that shift economic power, these direct regulatory interventions restructure exchange by setting absolute, non-negotiable conditions of market participation, including outright bans on specific activities, like selling sex for money or employing child labor (Radin 1996; Zelizer 1994). The social mechanisms that reconfigure authoritative power along these lines, then, can be thought of as conditional blockages, named for the ways they authoritatively and absolutely block particular forms of economic activity unless specific conditions are met. Thus, for example, the state may insist that if carbon polluters want to emit $\mathrm{CO}_{2}$ they must buy carbon credits; that if land developers want to build, they must provide habitat offsets; that if business owners want to hire employees, they must hire adults and not children. These are requirements, in short, that use direct, authoritative commands to reconfigure exchange in markets - markets in energy production, developable land, and labor in the previous examples. In the case of species conservation banking, mutual reinforcement of state and federal law in southern California, and ecologically-minded reinterpretations of the Endangered Species Act in northern California, acted as the conditional blockages that expanded authoritative regulatory power. These are the processes that allowed federal regulators to effectively make it mandatory for land developers to provide species offsets if the developers wanted to proceed with a building project.

Taken together, the concepts of exchange deterrents and conditional blockages offer a parsimonious but powerful means of tracing out how actors shift economic and authoritative power, and thus remake markets and reshape regulation. In terms of command-and-commodify regulation, the implication is clear: these particular institutions, which are characterized by high levels of both authoritative and economic forms of power, can emerge where social struggles reconstruct markets via imposing both conditional blockages and exchange deterrents - that is, where social struggles push forward coupled expansions of both authoritative and economic regulatory power together. Note that tautologies must be carefully avoided in such a formulation; command-and-commodify regulation is of course likely to develop where authoritative and economic power are expanded together. This is true by definition. But identifying how particular social conflicts and processes impose or remove specific exchange deterrents and conditional blockages - the mechanisms of action in theory of market reconstruction - offers a clear, politically and historically-specific means for explaining how and where command-andcommodify institutions develop in specific times and places.

This framework also offers a means of understanding the emergence of other forms of regulation - or, taking command-and-commodify regulation as a reference point, makes it possible to explain how and why other forms of regulation did not emerge in specific cases. Thus, in the case of species conservation banking in California, and as research by Bartley (2007) elegantly demonstrates, had the process of market reconstruction only worked along the axis of economic power - that is, if exchange deterrents in the form of legal pressure and business-friendly efficiency arguments had not been accompanied by authoritative demands for habitat offsets - then a voluntary market in species credits might have emerged in California. Rather than command-and-commodify regulation, social scientists would find a form of private regulation. Conversely, if the processes of market reconstruction had only worked along the axis of authoritative power - that is, if conditional blockages in the form of authoritative demands for offsetting had not been accompanied by legal suits and efficiency arguments that made species conservation banking 'make sense' to land developers - then a more familiar and authoritative form of command-and-control regulation might have developed, and this article would be focused on new authoritatively-imposed limits on land development with no associated market 
mechanisms. Analytically separating authoritative and economic forms of power, and then tracing the ways social conflicts expand (or fail to expand) power along these dimensions, makes it possible to explain how and why a particular regulatory institution emerged where it did and why its institutional morphology is as it is.

\section{Towards a sociology of power, regulation, and environment}

Coupling a theory of market reconstruction to the command-and-commodify framework makes several contributions to sociological knowledge of market formation, regulation, and, given the empirical focus of this article, environmental protection. To research that lies at the intersection of social movements, organizations, and markets (for reviews see King and Pearce 2010; Soule 2012; Walker 2012), the approach I offer here provides a clear means of identifying and tracing out the ways that mobilization and political contention push market reconstruction, regulatory reform, and institutional emergence in particular directions, towards more state-led (commandand-control), market-led (private), or state-led but market-oriented (command-and-commodify) regulatory institutions. In terms of environmental regulation in particular, this approach helps explain how political pressure for states to address large and growing environmental problems intersects with the continuing influence of pro-business, pro-market politics to produce hybrid command-and-commodify institutions, which simultaneously expand state authority to limit some forms of economic activity, while also building new markets that appeal to pro-market politicians, publics, and leaders. More generally, my approach also brings concepts of power directly into institutional theory - concepts that researchers regularly make reference to, but rarely put to direct analytical use.

To sociological research on regulation, the command-and-commodify framework offers a means of clearly differentiating between similar-seeming regulatory institutions, particularly those that integrate market elements. Social scientists have long recognized that, even in an era of economic liberalization, many examples of regulatory marketization seem to be, "more about revising relations between states, rulemaking, and markets than about simply replacing one form with another" (Schneiberg and Bartley 2008: 47). Drawing distinctions between authoritative and economic forms of power offers a first step for sorting out how these revisions can occur. For instance, the framework I suggest makes it clear that private forms of regulation are characterized by low levels of authoritative power - that is, they are almost entirely voluntary. As previously noted, this includes things like private product certification schemes, but in environmental policy it also includes widely discussed 'payments for ecosystem services' approaches, wherein actors are paid - but never directly coerced - to take ecologically (and thus socially) beneficial actions, like preserving forest cover (e.g. the United Nations Programme on Reducing Emissions from Deforestation and Forest Degradation) or upgrading wastewater systems that pollute drinking water. But command-and-commodify institutions like species conservation banking and even cap-and-trade are often lumped in with discussions of payments for ecosystem services approaches (e.g. Mercer et al. 2011). In the superficial sense that both approaches involve exchanges of money for nature this is fair, but the command-and-commodify framework makes clear that these are in fact quite different institutions: not only do most payments for ecosystem services schemes lack the authoritative teeth that characterize command-and-commodify institutions (cf. Wunder 2005; Engel et al. 2008), but the social and political processes needed to reconstruct power, and thus to create each of these institutions, are quite different. The implications for policymakers, advocates, and even researchers are clear enough: not all market-oriented forms of regulation are the same, and the political work and 
mobilization required to build new a regulatory institution depends upon what kind of regulation one aims for in the first place.

Finally, the approach I offer here contributes directly to efforts in environmental sociology, political ecology, and related fields to move beyond well-worn debates that tend to see marketoriented environmental reforms as either essential technologies of a sustainable future, or as little else but the latest expansion of neoliberal capitalism. ${ }^{16}$ A number of authors have recently contributed to transcending this binary, highlighting the ways that not just innovation or accumulation, but "a broad array of goals - political, social, cultural, and environmental... both drive and mediate the neoliberalization of nature" (Bakker 2009: 1783; see also White et al. 2016). Researchers have shown, for example, that the politics of knowledge production, the legitimacy of environmental professionals and their opinions, and cultural-legal views of the value of nature itself are all central to understanding how new markets in nature work and emerge (Fourcade 2011; Lave 2012a; Gareau 2013). The crucial role of ecological arguments in favor of species conservation banking highlights this point. Scholars have also called attention to the ways that markets are not just embedded in 'society,' but in nature too, which in turn suggests that movements of environmental protection can be thought of as efforts to 're-embed' nature within particular cultural, political, and economic institutions (Kaup 2015). Somewhat ironically, and as this article shows, it would seem that such market-protective efforts can themselves include market mechanisms, the way that cap-and-trade or species conservation banking depend upon creating markets in offset credits in order to help protect ecological resources (see also Carton 2014).

This is not to say that these new and often market-oriented regulatory institutions transcend or even fully address many of the largest social problems of our day, environmental or otherwise. But observing the complexity that undergirds these novel forms of regulation does call for nuanced accounts of how regulatory institutions of all kinds - especially market-oriented onesemerge and work. Explaining the development of things like command-and-commodify regulation, after all, requires moving beyond macro-theories of capitalism, or focusing narrowly on policy innovation and entrepreneurship. Rather, it demands a more intimate account, one that digs deeper into the nitty-gritty politics, the related reconfigurations of power, and above all else, the continuous efforts of people working, always imperfectly, to reconstruct and remake the institutions that shape the world we live in.

\section{References}

Andrews, Kenneth T. and Charles Seguin. 2015. "Group Threat and Policy Change: The Spatial Dynamics of Prohibition Politics, 1890-1919.” American Journal of Sociology 121:475-510.

Andrus, Cecil. 1981. "U.S. Fish and Wildlife Service Mitigation Policy.” Federal Register 46:7656-7663.

Bailey, Ian, Andy Gouldson, and Peter Newell. 2011. "Ecological Modernisation and the Governance of Carbon: A Critical Analysis.” Antipode 43:682-703.

Bakker, Karen. 2005. "Neoliberalizing Nature? Market Environmentalism in Water Supply in England and Wales." Annals of the Association of American Geographers 95:542-565.

\footnotetext{
${ }^{16}$ For a nice summary of this debate see White et al. (2016), especially chapter 5.
} 
Bakker, Karen. 2009. "Neoliberal nature, ecological fixes, and the pitfalls of comparative research.” Environment and Planning A 41:1781-1787.

Bartley, Tim. 2007. "Institutional Emergence in an Era of Globalization: The Rise of Transnational Private Regulation of Labor and Environmental Conditions." American Journal of Sociology 113:297-351.

Beck, Ulrich. 1992. Risk Society: Towards a New Modernity. SAGE.

Beck, Ulrich, Anthony Giddens, and Scott Lash. 1994. Reflexive Modernization: Politics, Tradition and Aesthetics in the Modern Social Order. Stanford University Press.

Besky, Sarah. 2013. The Darjeeling Distinction. University of California Press.

Block, Fred. 2013. "Relational Work and the Law: Recapturing the Legal Realist Critique of Market Fundamentalism." Journal of Law and Society 40:27-48.

Brockington, Dan and Rosaleen Duffy. 2010. "Capitalism and Conservation: The Production and Reproduction of Biodiversity Conservation." Antipode 42:469-484.

Büscher, Bram, Sian Sullivan, Katja Neves, Jim Igoe, and Dan Brockington. 2012. "Towards a Synthesized Critique of Neoliberal Biodiversity Conservation." Capitalism Nature Socialism 23:4-30.

Buttel, Frederick H. 2000. "Ecological Modernization as Social Theory.” Geoforum 31:57-65.

California Department of Transportation. 2011. "Madera Pools Restoration and Mitigation Site." Exemplary Ecosystem Initiative Application .

Campbell, Andrea Louise. 2003. How Policies Make Citizens: Senior Political Activism and the American Welfare State. Princeton University Press.

Campbell, John L. and Leon N. Lindberg. 1990. "Property Rights and the Organization of Economic Activity by the State." American Sociological Review 55:634-647.

Carroll, Nathaniel, Jessica Fox, and Ricardo Bayon (eds.). 2009. Conservation and Biodiversity Banking: A Guide to Setting Up and Running Biodiversity Credit Trading Systems. Routledge.

Carruthers, Bruce G. and Laura Ariovich. 2004. "The Sociology of Property Rights." Annual Review of Sociology 30:23-46.

Carton, Wim. 2014. "Environmental Protection as Market Pathology?: Carbon Trading and the Dialectics of the 'Double Movement'." Environment and Planning D: Society and Space 32:1002-1018.

Castree, Noel. 2008. "Neoliberalising Nature: The Logics of Deregulation and Reregulation." Environment and Planning A 40:131-152.

Clark, Brett and Richard York. 2005. "Carbon Metabolism: Global Capitalism, Climate Change, and the Biospheric Rift." Theory and Society 34:391-428.

Coase, Ronald Harry. 1960. "The Problem of Social Cost." Journal of Law and Economy 3:144.

Dales, John H. 1968a. "Land, Water, and Ownership." The Canadian Journal of Economics/Revue canadienne d'Economique 1:791-804.

Dales, John H. 1968b. Pollution, Property \& Prices: An Essay in Policy-Making and Economics. Edward Elgar Pub.

Ecosystem Marketplace. 2011. "The State of Biodiversity Markets."

Edelman, Lauren B. 1992. "Legal Ambiguity and Symbolic Structures: Organizational Mediation of Civil Rights Law.” American Journal of Sociology 97:1531-1576. 
Edelman, Lauren B., Christopher Uggen, and Howard S. Erlanger. 1999. "The Endogeneity of Legal Regulation: Grievance Procedures as Rational Myth.” American Journal of Sociology 105:406-54.

Ellerman, A. Denny and Barbara K. Buchner. 2007. "The European Union Emissions Trading Scheme: Origins, Allocation, and Early Results." Review of Environmental Economics and Policy 1:66-87.

Ellerman, A. Denny, Paul L. Joskow, Richard Schmalensee, Juan-Pablo Montero, and Elizabeth M. Bailey. 2000. Markets for Clean Air: The U.S. Acid Rain Program. Cambridge University Press.

Engel, S., S. Pagiola, and S. Wunder. 2008. "Designing Payments for Environmental Services in Theory and Practice: An Overview of the Issues." Ecological Economics 65:663-674.

Engels, Anita. 2006. "Market Creation and Transnational Rule-Making: The Case of $\mathrm{CO}_{2}$ Emissions Trading." In Transnational Governance: Institutional Dynamics of Regulation, edited by Marie-Laure Djelic and Kerstin Sahlin-Andersson, pp. 329-348. Cambridge University Press.

Feldman, Thomas D. and Andrew E. G. Jonas. 2000. "Sage Scrub Revolution? Property Rights, Political Fragmentation, and Conservation Planning in Southern California under the Federal Endangered Species Act." Annals of the Association of American Geographers 90:256-292.

Fligstein, Neil. 2001. The Architecture of Markets: An Economic Sociology of Twenty-FirstCentury Capitalist Societies. Princeton University Press.

Fligstein, Neil and Luke Dauter. 2007. "The Sociology of Markets." Annual Review of Sociology 33:105-128.

Foster, John Bellamy, Brett Clark, and Richard York. 2009. "The Midas effect: A critique of climate change economics." Development and Change 40:1085-1097.

Fourcade, Marion. 2011. "Cents and Sensibility: Economic Valuation and the Nature of "Nature"." American Journal of Sociology 116:1721-77.

Fourcade, Marion and Kieran Healy. 2007. "Moral Views of Market Society." Annual Review of Sociology 33:285-311.

Fox, Jessica and Anamaria Nino-Murcia. 2005. "Status of Species Conservation Banking in the United States." Conservation Biology 19:996-1007.

Frank, David J., Ann Hironaka, and Evan Schofer. 2000. "The Nation-State and the Natural Environment Over the Twentieth Century." American Sociological Review pp. 96-116.

Funk, Russell J. and Daniel Hirschman. 2014. "Derivatives and Deregulation Financial Innovation and the Demise of Glass-Steagall.” Administrative Science Quarterly 59:669704.

Gareau, Brian J. 2013. From Precaution to Profit: Contemporary Challenges to Environmental Protection in the Montreal Protocol. Yale University Press.

Golub, Jonathan (ed.). 1998. New Instruments for Environmental Policy in the EU. Routledge.

Gottlieb, Robert. 2005. Forcing the Spring: The Transformation of the American Environmental Movement. Island Press.

Guthman, Julie. 2007. "The Polanyian way? Voluntary food labels as neoliberal governance." Antipode 39:456-478.

Hale, Robert L. 1935. "Force and the State: A Comparison of "Political" and "Economic" Compulsion." Columbia Law Review 35:149. 
Hale, Robert L. 1943. "Bargaining, Duress, and Economic Liberty." Columbia Law Review 43:603-628.

Harvey, David. 1996. Justice, Nature and the Geography of Difference. Wiley-Blackwell, 1st edition.

Ingram, Paul., Lori Q. Yue, and Hayagreeva Rao. 2010. "Trouble in Store: Probes, Protests, and Store Openings by Wal-Mart, 1998-20071.” American Journal of Sociology 116:5392.

Kaplan, Rami. 2015. "Who has been regulating whom, business or society? The mid-20thcentury institutionalization of 'corporate responsibility' in the USA." Socio-Economic Review 13:125-155.

Kaup, Brent Z. 2015. "Markets, Nature, and Society Embedding Economic \& Environmental Sociology." Sociological Theory 33:280-296.

Kettl, Donald F. 1993. Sharing Power: Public Governance and Private Markets. Brookings Institution Press.

Kettl, Donald F. 2002. The Transformation of Governance: Public Administration for TwentyFirst Century America. Baltimore: Johns Hopkins University Press.

Kinderman, Daniel. 2011. “'Free us up so we can be responsible!' The co-evolution of Corporate Social Responsibility and neo-liberalism in the UK, 1977-2010.” SocioEconomic Review p. mwr028.

King, Brayden G and N. A Pearce. 2010. "The Contentiousness of Markets: Politics, Social Movements, and Institutional Change in Markets." Annual Review of Sociology 36:249 267.

Klare, Karl E. 1988. "Workplace Democracy and Market Reconstruction: An Agenda for Legal Reform." Catholic University Law Review 38:1.

Lamb, Celia. 2007. "State buys wetland credits to build highway." Sacramento Business Journal. Sunday, March 11, 2007.

Lave, Rebecca. 2012a. "Bridging Political Ecology and STS: A Field Analysis of the Rosgen Wars." Annals of the Association of American Geographers 102:366-382.

Lave, Rebecca. 2012b. Fields and Streams: Stream Restoration, Neoliberalism, and the Future of Environmental Science. University of Georgia Press.

Lederer, Markus. 2012. "Market Making via Regulation: The Role of the State in Carbon Markets.” Regulation \& Governance 6:524-544.

Levien, Michael. 2013. "The Politics of Dispossession: Theorizing India's "Land Wars"." Politics \& Society 41:351-394.

Levin, Peter and Wendy N. Espeland. 2002. "Pollution Futures: Commensuration, Commodification, and the Market for Air." In Orginizations, Policy, and the Natural Environment, edited by Andrew J. Hoffman and Marc J. Ventresca, pp. 119-147. Stanford University Press.

Locke, Richard M. 2013. The Promise and Limits of Private Power: Promoting Labor Standards in a Global Economy. Cambridge University Press.

Lockhart, Andy. 2015. "Developing an offsetting programme: tensions, dilemmas and difficulties in biodiversity market-making in England." Environmental Conservation 42:335-344.

Lohmann, Larry. 2010. "Neoliberalism and the Calculable World: The Rise of Carbon Trading." In The Rise and Fall of Neoliberalism: The Collapse of an Economic Order?, edited by Kean Birch and Vald Mykhnenko. Zed Books. 
MacKenzie, Donald. 2009. "Making Things the Same: Gases, Emission Rights and the Politics of Carbon Markets." Accounting, Organizations and Society 34:440-455.

McCright, Aaron M. and Riley E. Dunlap. 2003. "Defeating Kyoto: The Conservative Movement's Impact on U.S. Climate Change Policy." Social Problems 50:348-373.

Meckling, Jonas. 2011. Carbon Coalitions: Business, Climate Politics, and the Rise of Emissions Trading. MIT Press.

Mercer, D. Evan, David Cooley, and Katherine Hamilton. 2011. "Taking Stock: Payments for Ecosystem Services in the United States." A report published by Forest Trends. Available at http://www.forest-trends.org/documents/files/doc_2673.pdf

Merton, Robert K. 1987. "Three Fragments From a Sociologist's Notebooks: Establishing the Phenomenon, Specified Ignorance, and Strategic Research Materials." Annual Review of Sociology 13:1-29.

Mol, Arthur P. J. 2012. "Carbon flows, financial markets and climate change mitigation." Environmental Development 1:10-24.

Mol, Arthur P. J. and David A. Sonnenfeld. 2000. "Ecological Modernisation Around the World: An Introduction." Environmental Politics 9:1-14.

Mol, Arthur P. J. and Gert Spaargaren. 2000. "Ecological Modernisation Theory in Debate: A Review." Environmental Politics 9:17-49.

Obama, Barack. 2016. "United states health care reform: Progress to date and next steps." Journal of the American Medical Association .

Polanyi, Karl. 2001. The Great Transformation: The Political and Economic Origins of Our Time. Beacon Press.

Quinn, Sarah. 2008. "The Transformation of Morals in Markets: Death, Benefits, and the Exchange of Life Insurance Policies.” American Journal of Sociology 114:738-780.

Radin, Margaret Jane. 1996. Contested Commodities. Harvard University Press.

Rao, Hayagreeva, Calvin Morrill, and Mayer N Zald. 2000. "Power Plays: How Social Movements and Collective Action Create New Organizational Forms." Research in Organizational Behavior 22:237-282.

Rao, Hayagreeva, Lori Qingyuan Yue, and Paul Ingram. 2011. "Laws of Attraction Regulatory Arbitrage in the Face of Activism in Right-to-Work States." American Sociological Review 76:365-385.

Robertson, Morgan M. 2004. "The Neoliberalization of Ecosystem Services: Wetland Mitigation Banking and Problems in Environmental Governance." Geoforum 35:361-373.

Robertson, Morgan M. 2006. "The Nature That Capital Can See: Science, State, and Market in the Commodification of Ecosystem Services." Environment and Planning D: Society and Space 24:367-387.

Roy, William G. 1997. Socializing Capital: The Rise of the Large Industrial Corporation in America. Princeton University Press.

Rudel, Thomas K., J. Timmons Roberts, and JoAnn Carmin. 2011. "Political Economy of the Environment." Annual Review of Sociology 37:221-238.

Salzman, James. 2005. "Creating Markets for Ecosystem Services: Notes from the Field." New York University Law Review 80:870-961.

Schneiberg, Marc and Tim Bartley. 2001. "Regulating American Industries: Markets, Politics, and the Institutional Determinants of Fire Insurance Regulation." American Journal of Sociology 107:101-146. 
Schneiberg, Marc and Tim Bartley. 2008. "Organizations, Regulation, and Economic Behavior: Regulatory Dynamics and Forms from the Nineteenth to Twenty-First Century." Annual Review of Law and Social Science 4:31-61.

Sinclair, Darren. 1997. "Self-regulation versus command and control? Beyond false dichotomies." Law \& Policy 19:529-559.

Sine, Wesley D and Brandon H Lee. 2009. "Tilting at Windmills? The Environmental Movement and the Emergence of the U.S. Wind Energy Sector." Administrative Science Quarterly 54:123-155.

Small, Mario L. 2009. “'How many cases do I need?': On Science and the Logic of Case Selection in Field-Based Research." Ethnography 10:5-38.

Smith, Neil. 2007. "Nature as Accumulation Strategy.” Socialist Register 2007:16.

Soule, Sarah A. 2009. Contention and Corporate Social Responsibility. Cambridge University Press.

Soule, Sarah A. 2012. "Social Movements and Markets, Industries, and Firms.” Orginization Studies 33:1715-1733.

Spaargaren, Gert and Arthur P. J. Mol. 2013. "Carbon flows, carbon markets, and low-carbon lifestyles:reflecting on the role of markets in climategovernance." Environmental Politics 22:174-193.

Swedberg, Richard. 2005. "Markets in Sociology." In The Handbook of Economic Sociology, edited by Neil J. Smelser and Richard Swedberg, pp. 233-253. Princeton University Press; Russell Sage Foundation, 2nd edition.

Swyngedouw, Erik. 2005. "Dispossessing $\mathrm{H}_{2} \mathrm{O}$ : The Contested Terrain of Water Privatization." Capitalism Nature Socialism 16:81-98.

Tietenburg, T. H. 2006. Emissions Trading: Principles and Practice. Resources for the Future.

U.S. Fish and Wildlife Service and National Marine Fisheries Service. 1998. "Endnagered Speices Act Consultation Handbook: Procedures for Conducting Section 7 Consultations and Conferences."

Vogel, David. 2005. The Market for Virtue: The Potential and Limits of Corporate Social Responsibility. Brookings Institution Press.

Vogel, David. 2008. "Private Global Business Regulation." Annual Review of Political Science 11:261-282.

Vogel, David. 2012. The Politics of Precaution: Regulating Health, Safety, and Environmental Risks in Europe and the United States. Princeton N.J.: Princeton University Press.

Vogel, Steven Kent. 1996. Freer Markets, More Rules: Regulatory Reform in Advanced Industrial Countries. Cornell University Press.

Vogel, Steven Kent. 2016. "Marketcraft: WhatDoes It Really Take to Make a Market Work?" In Woring Paper Presented at SASE Annual Conference. June 25. University of California, Berkeley.

Walker, Edward T. 2012. "Social Movements, Organizations, and Fields: a Decade of Theoretical Integration." Contemporary Sociology: A Journal of Reviews 41:576-587.

Walker, Edward T., Andrew W. Martin, and John D. McCarthy. 2008. "Confronting the State, the Corporation, and the Academy: The Influence of Institutional Targets on Social Movement Repertoires." American Journal of Sociology 114:35-76.

Walker, Edward T. and Christopher M. Rea. 2014. "The Political Mobilization of Firms and Industries." Annual Review of Sociology 40.

Washington State. 1971. "State Environmental Policy Act." 
Weber, Klaus, Hayagreeva Rao, and L. G. Thomas. 2009. "From Streets to Suites: How the Anti-Biotech Movement Affected German Pharmaceutical Firms." American Sociological Review 74:106-127.

Weber, Max. 1978. Economy and Society: An Outline of Interpretive Sociology. University of California Press.

White, Damian, Alan Rudy, and Brian Gareau. 2016. Environments, Natures and Social Theory: Towards a Critical Hybridity. Palgrave Macmillan.

Widick, Richard. 2009. Trouble in the Forest: California's Redwood Timber Wars. University of Minnesota Press.

World Bank. 2014. "State and Trends of Carbon Pricing 2014."

Wunder, S. 2005. Payments for Environmental Services: Some Nuts and Bolts, volume Occasional Paper No. 42. Center for International Forestry Research.

Zelizer, Viviana A. Rotman. 1978. "Human Values and the Market: The Case of Life Insurance and Death in 19th-Century America." American Journal of Sociology 84:591610.

Zelizer, Viviana A. Rotman. 1994. Pricing the Priceless Child: The Changing Social Value of Children. Princeton University Press.

Zelizer, Viviana A. Rotman. 2011. Economic Lives: How Culture Shapes the Economy. Princeton University Press. 


\section{Figures}

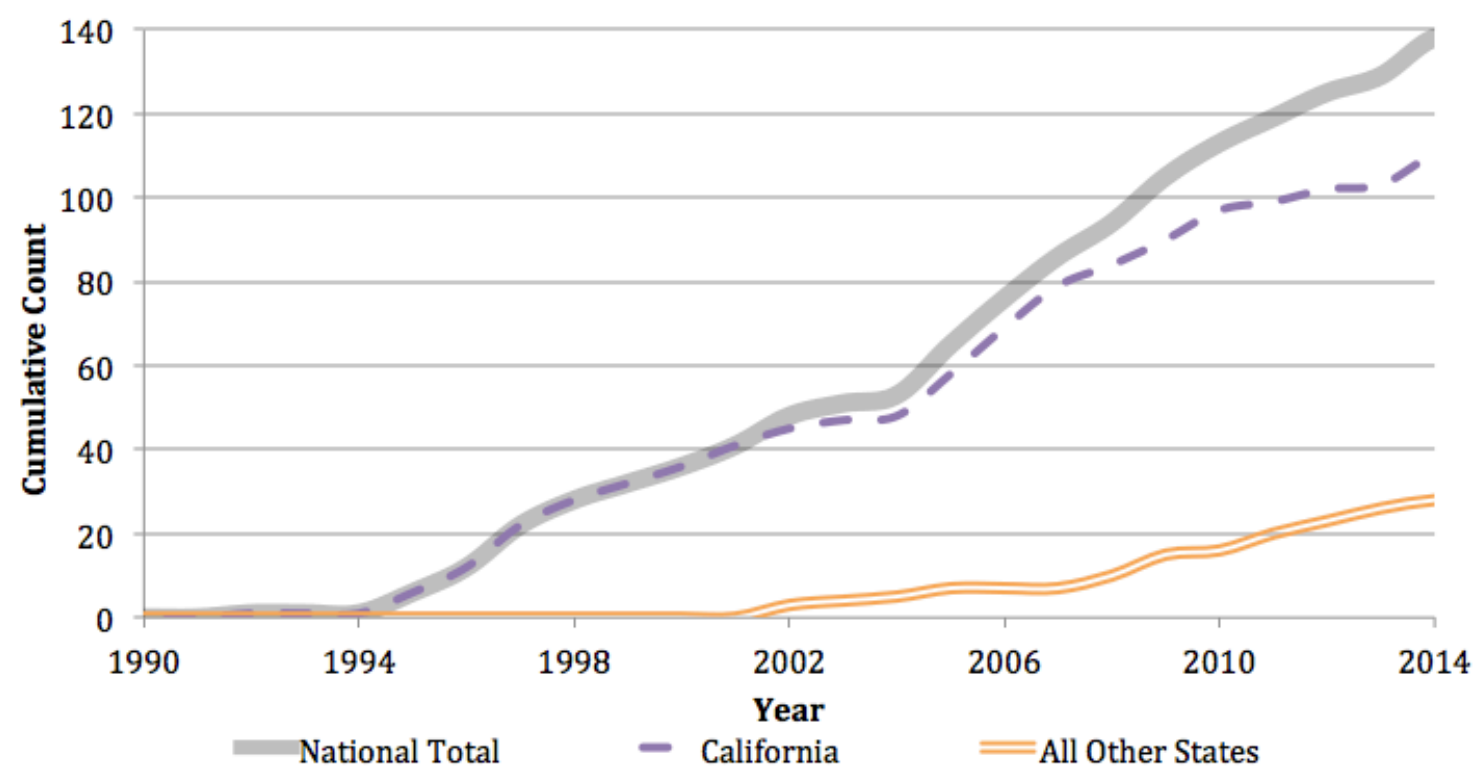

Figure 1: Species conservation banks in the U.S., California, and all other states.

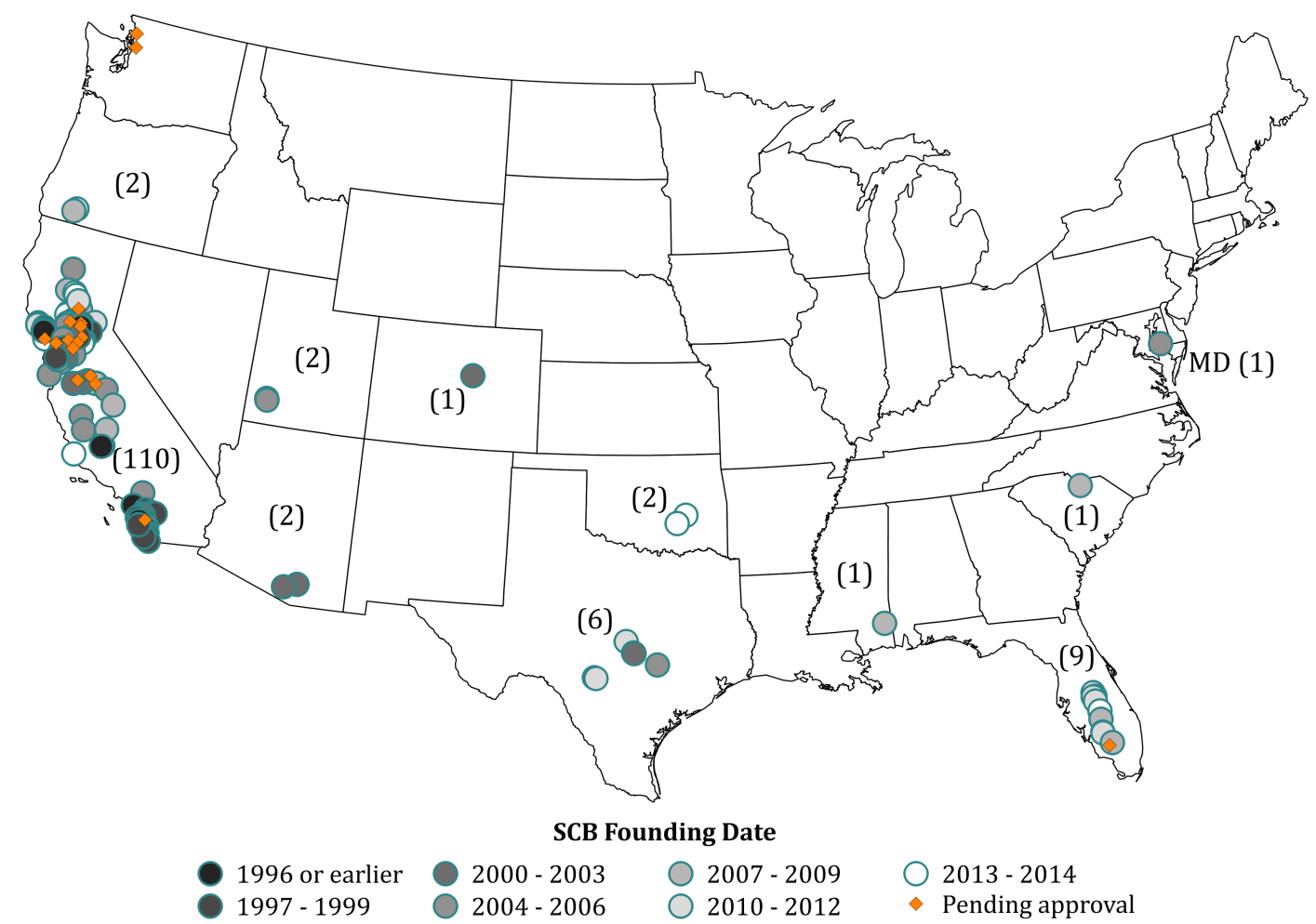

Figure 2: Location, founding dates, and state counts of 137 approved species conservation banks in the United States through 2014. 


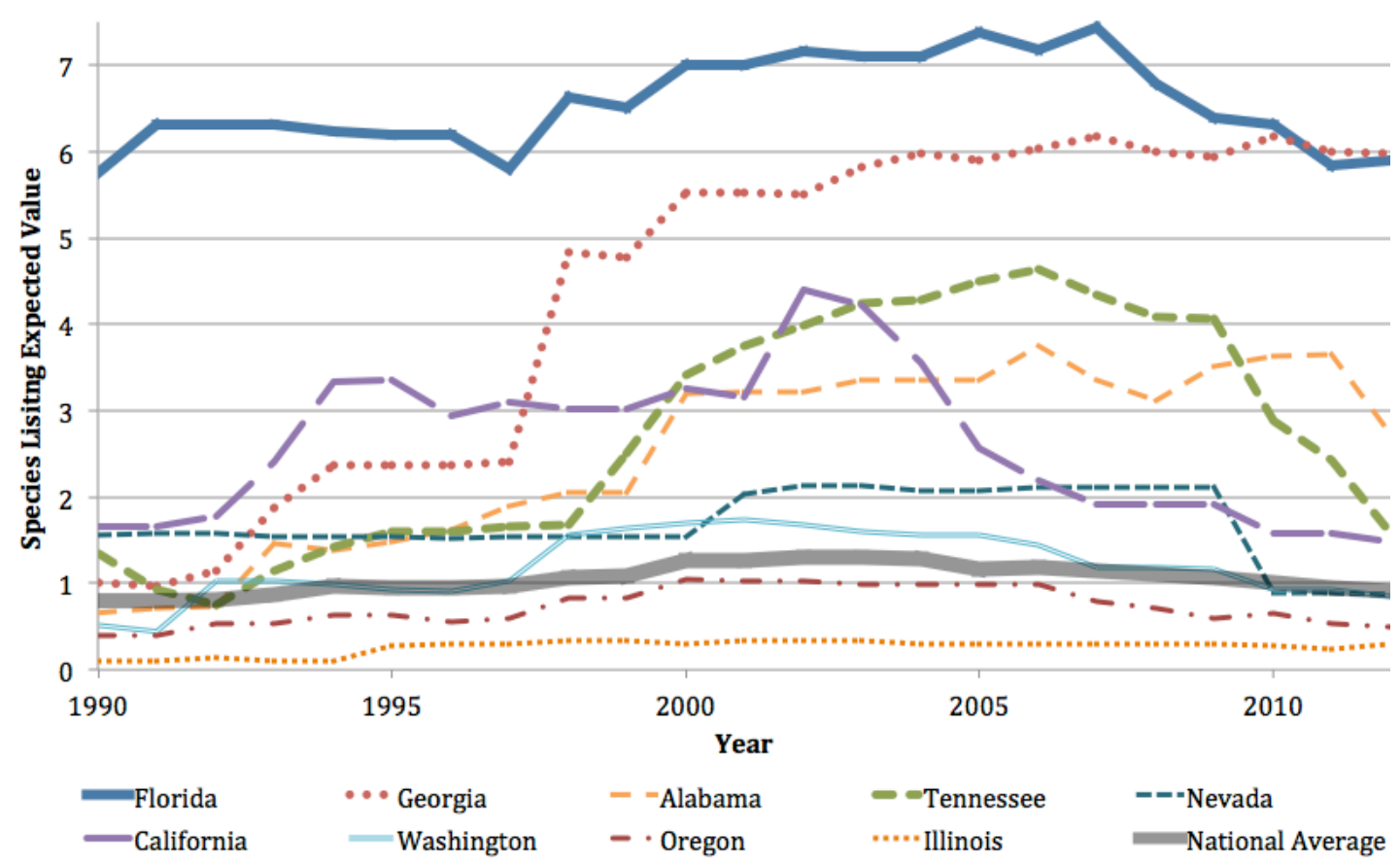

Figure 3: County-level species listing expected values (SLEV) from 1990 to 2012 for selected states. SLEV estimates overlap between land development and endangered species habitat.

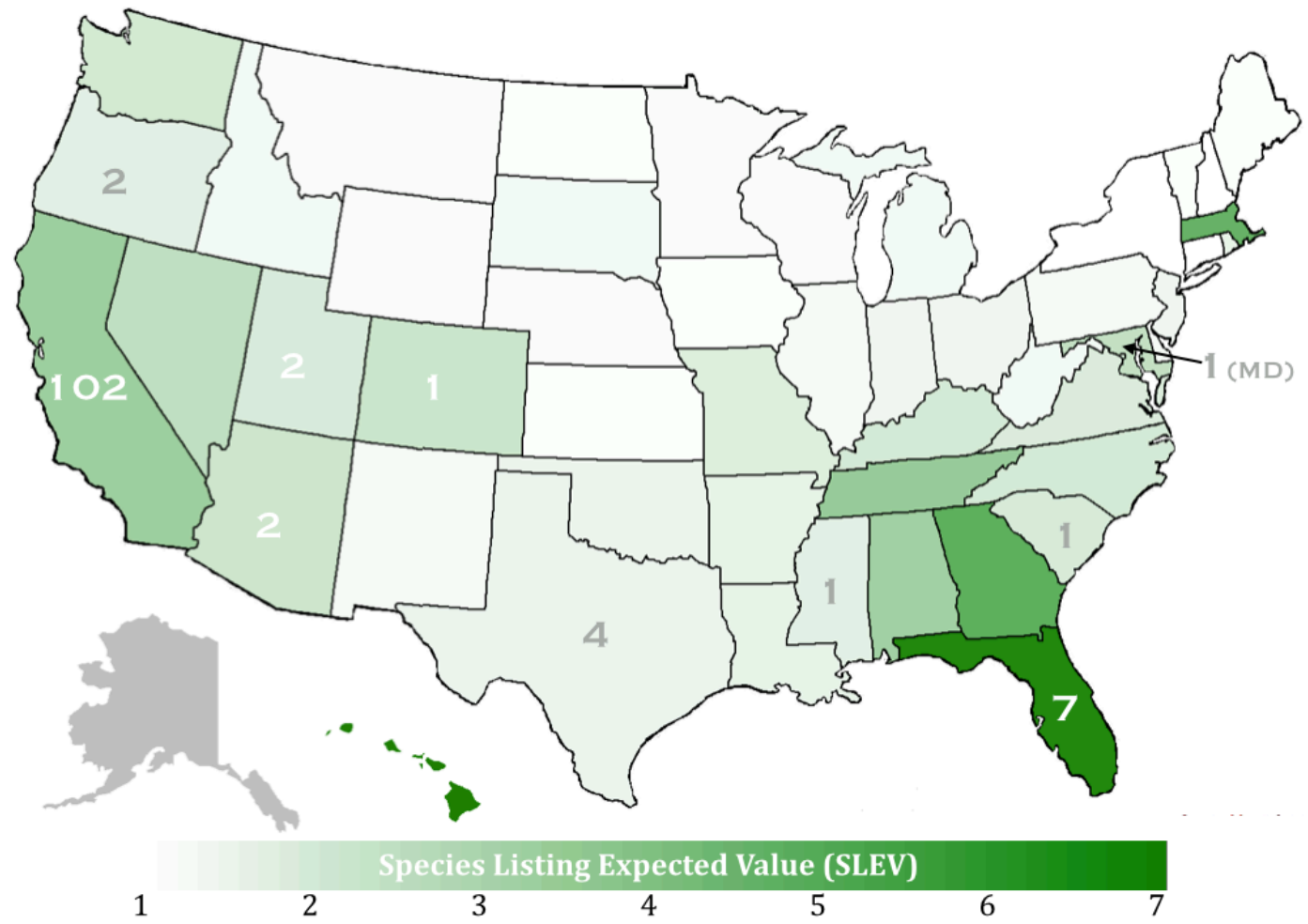

Figure 4: Averaged annual species listing expected values (SLEV), 1990 to 2012 (table A3), overlaid with state counts of SCBs in 2012. Alaska SLEV not calculated. 


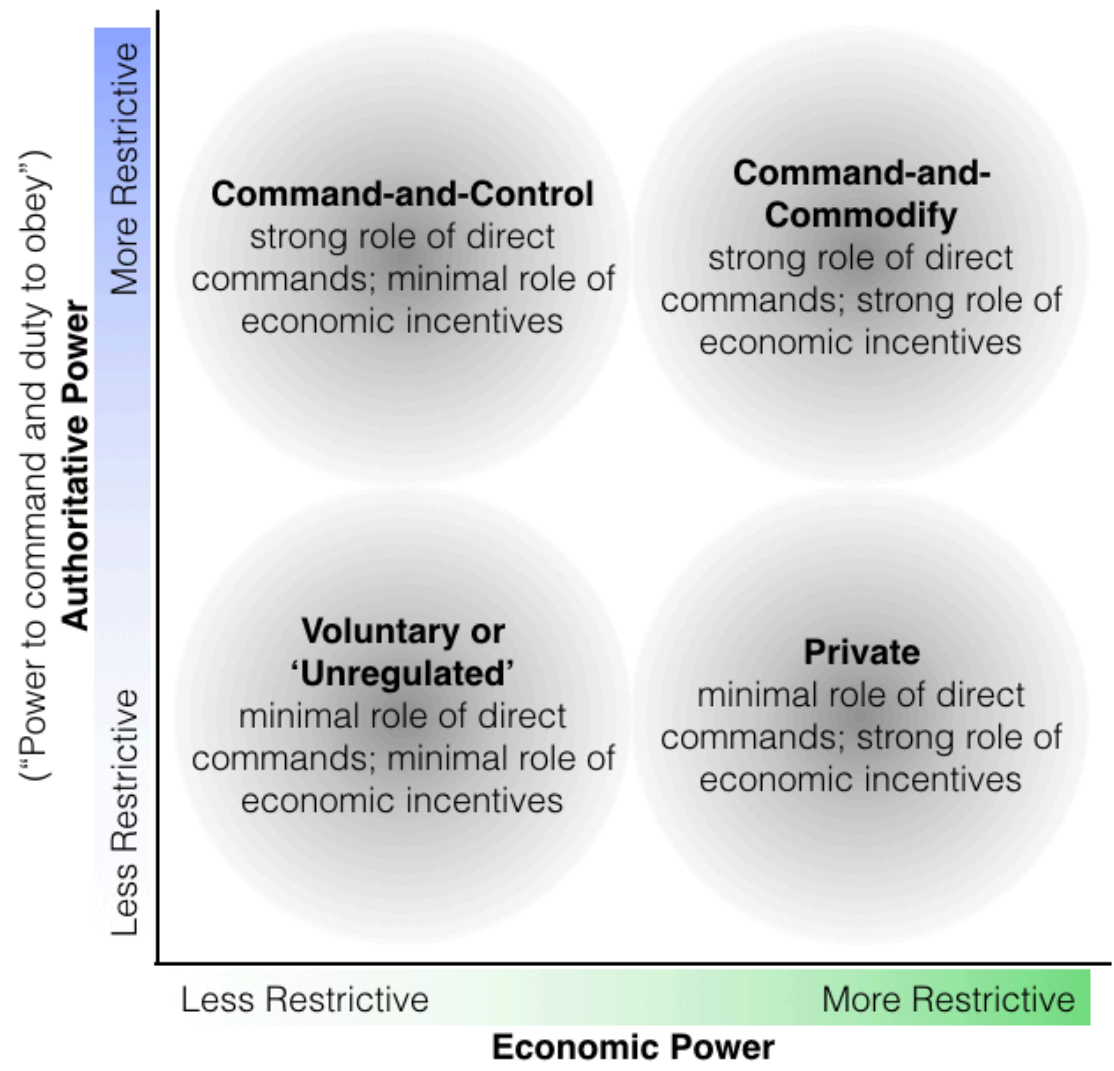

("Domination by a constellation of interests")

Figure 5: Configurations of authoritative and economic power in four modes of regulation.

(A)

restructuring

of economic action

(B)

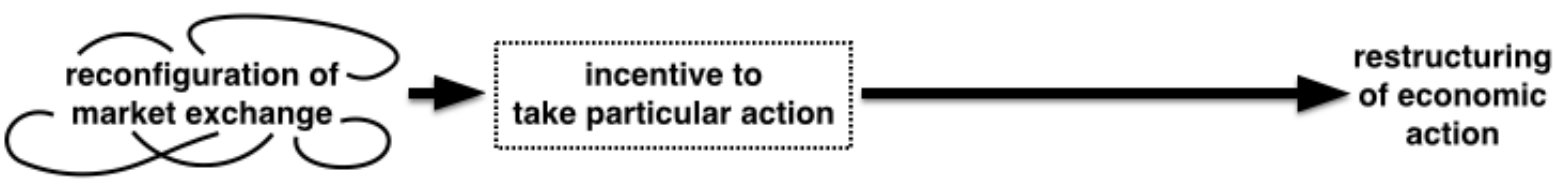

(C)
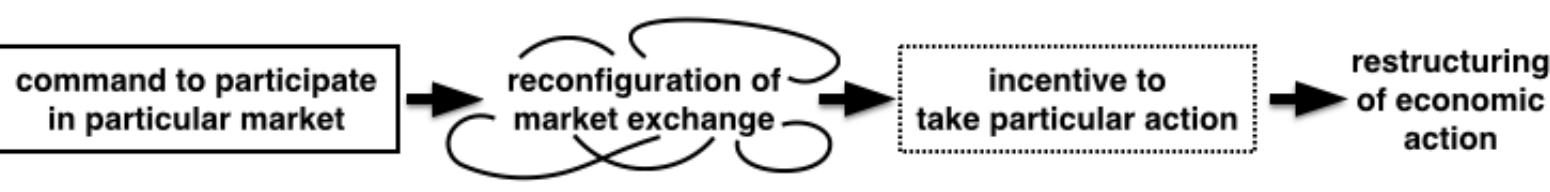

Figure 6: Modes of (re)structuring economic action in (A) command-and-control, (B) private, and (C) command-and-commodify regulatory institutions. 


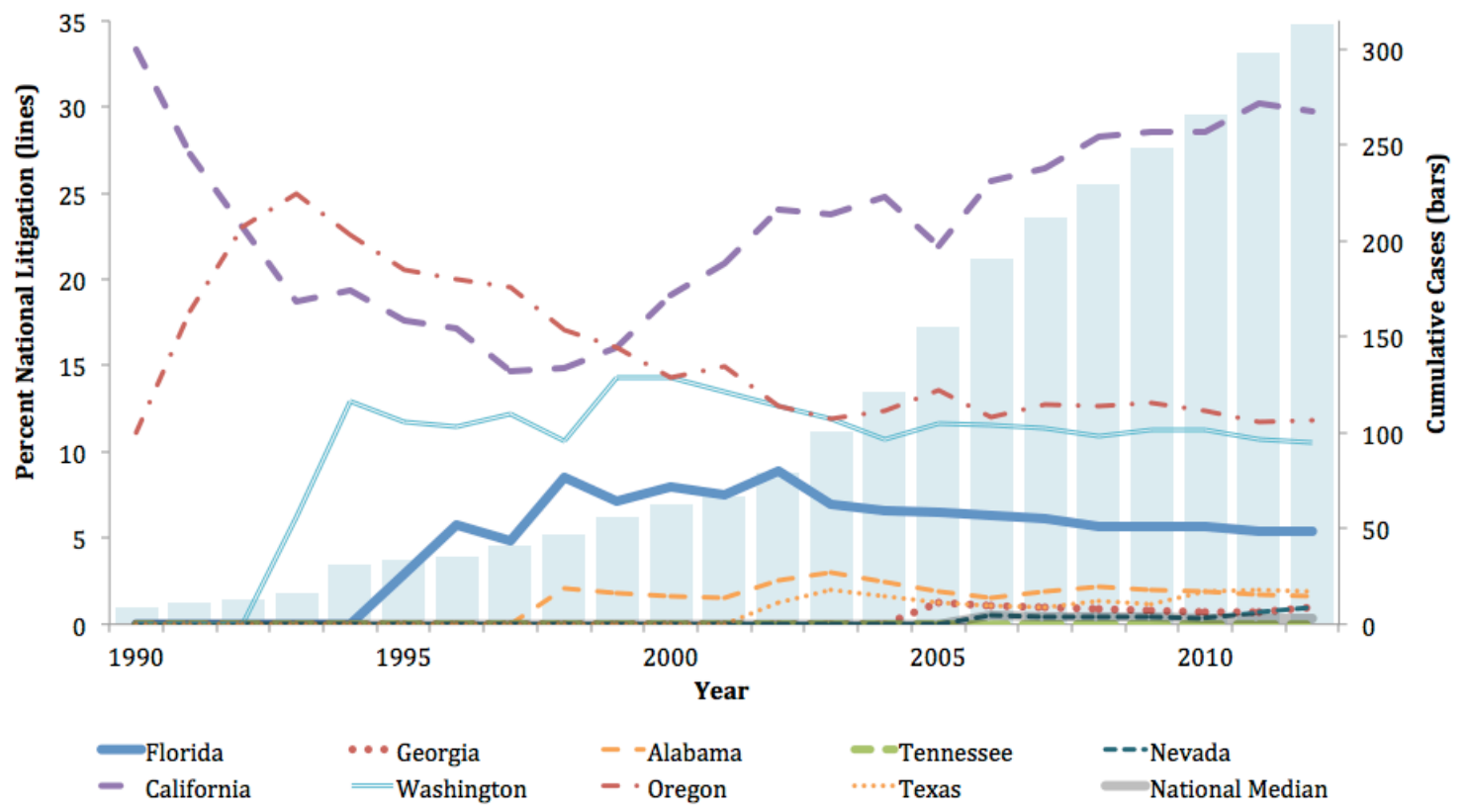

Figure 7: Cumulative shares of Endangered Species Act-related litigation for selected states, 1990 to $2012\left(\mathrm{~N}_{2012}=313\right) .1985$ baseline.

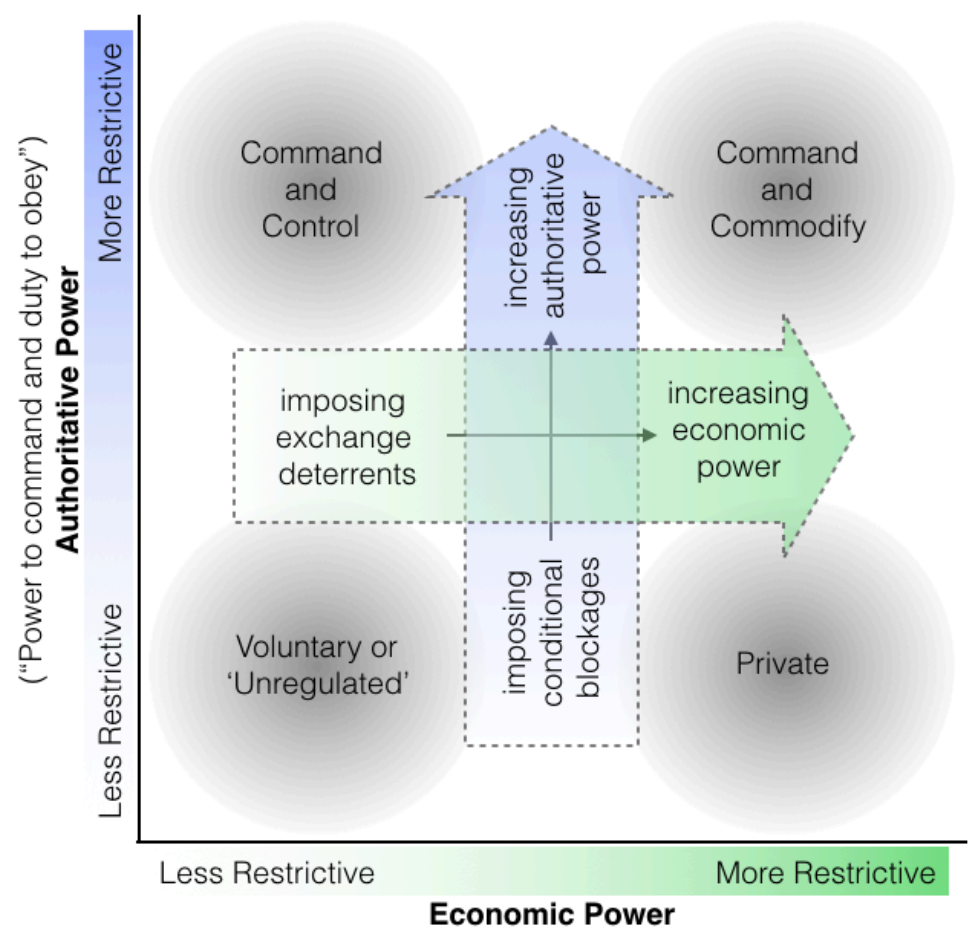

("Domination by a constellation of interests")

Figure 8: The role of conditional blockages and exchange deterrents in reconfiguring institutionalized modes of domination. Note that emergence of command-and-commodify regulation requires coupled expansions of authoritative and economic forms of power caused by the imposition of both conditional blockages and exchange deterrents. 


\section{Tables}

Table 1: Aggregate ESA-Related Litigation (1985-2012) in States with Ten Highest SLEVs

\begin{tabular}{lccc}
\hline \hline State & $\begin{array}{c}\text { Mean SLEV, } \\
\mathbf{1 9 9 0 - 2 0 1 2}\end{array}$ & $\begin{array}{c}\text { Total Cases } \\
\text { (\% of national) }\end{array}$ & $\begin{array}{c}\text { Agency as Defendant } \\
\text { (\% of national) }\end{array}$ \\
\hline Hawaii & 6.91 & $(1.9)$ & 5 \\
& & 17 & $(1.8)$ \\
Florida & 6.56 & $(5.4)$ & 16 \\
& & 3 & $(5.6)$ \\
Georgia & 4.38 & $(1.0)$ & 2 \\
& & 1 & $(0.7)$ \\
Massachusetts & 4.16 & $(0.3)$ & 1 \\
& & 0 & $(0.4)$ \\
Tennessee & 2.73 & $(0.0)$ & 0 \\
& & 93 & $(0.0)$ \\
California & 2.61 & $(29.7)$ & 82 \\
& & 5 & $(28.8)$ \\
Alabama & 2.50 & $(1.6)$ & 5 \\
& & 3 & $(1.8)$ \\
Nevada & 1.68 & $(1.0)$ & 3 \\
& & 2 & $(1.1)$ \\
Maryland & 1.57 & $(0.6)$ & 2 \\
Arizona & & 20 & $(0.7)$ \\
& & $(6.4)$ & 20 \\
Nat. Median & 1.39 & 1 & $(7.0)$ \\
N & & $(0.3)$ & 1 \\
& & $\mathbf{3 1 3}$ & $\mathbf{2 8 5}$ \\
\hline
\end{tabular}




\section{Appendix}

Table A1: Informant Counts by Organizational Affiliation and Geography ${ }^{\mathrm{a}}$

\begin{tabular}{lc}
\hline \hline Category & Count \\
\hline Organizational Affliation & \\
Conservation Banker & 14 \\
State Regulator & 10 \\
Federal Regulator & 18 \\
Environmental Impact Assessment & 7 \\
Environmental NGO & 7 \\
Land Development & 7 \\
Law & 2 \\
Total & 65 \\
Geographical Expertise & \\
California & 33 \\
Pacific Northwest & 7 \\
Southwest/Mountain States (excluding CA) & 3 \\
Midatlantic & 5 \\
Southeast & 8 \\
Midwest & 1 \\
National & 63 \\
Total & 63 \\
\hline a Totals do not sum to N=50 because informants often had experience \\
and expertise in multiple categories (e.g. worked in California and then \\
nationally, or first as a regulator then as a banker, etc.). & \\
& \\
&
\end{tabular}

Table A2: Fixed effects linear panel regression testing association with gross state product per capita in the construction industry, 1990-2012

\begin{tabular}{|c|c|}
\hline Variable & Coefficient \\
\hline \multirow[t]{2}{*}{ Percent population change in previous five years } & $76.23^{* * *}$ \\
\hline & $(4.14)$ \\
\hline \multirow[t]{2}{*}{ Year $\leq 1996^{\mathrm{b}}$} & $-322.24^{* * *}$ \\
\hline & $(21.01)$ \\
\hline \multirow[t]{2}{*}{ Constant } & $1528.79^{* * *}$ \\
\hline & $(25.57)$ \\
\hline \multicolumn{2}{|l|}{$r^{2}$ within $=0.36 ; r^{2}$ between $=0.51 ; r^{2}$ overall $=0.44$} \\
\hline \multicolumn{2}{|c|}{$\begin{array}{l}\mathrm{N}=1127 \text { with } 49 \text { groups (Alaska and the District of Columbia excluded) } \\
* * * p<.001 \\
\text { a For } 2005 \text { real dollars. The construction industry includes public civil en- } \\
\text { gineering projects as well as private development. For a complete list of } \\
\text { included economic activity and explanation, see http://www.census.gov/cgi- } \\
\text { bin/sssd/naics/naicsrch?chart_code }=23 \& \text { search }=2012 \% 20 \text { NAICS\%20Search } \\
\text { b Dummy variable to account for shift from the Standard Industrial Classi- } \\
\text { fication (SIC) to the The North American Industry Classification System } \\
\text { (NAICS) in } 1997 \text {. }\end{array}$} \\
\hline
\end{tabular}


Table A3: Mean state-year species listing expected values (SLEVs), 1990-2012.

\begin{tabular}{|c|c|c|c|c|}
\hline Rank & State & Mean SLEV & SCBs (2012) & \\
\hline 1 & Hawaii $^{\mathrm{a}}$ & 6.91 & 0 & \\
\hline 2 & Florida & 6.56 & 7 & \\
\hline 3 & Georgia & 4.38 & 0 & \\
\hline 4 & Massachusetts $^{a}$ & 4.16 & 0 & \\
\hline 5 & Tennessee & 2.73 & 0 & 90th Percentile (2.72) \\
\hline$\frac{\overline{6}}{6}--$ & Cālifornia & $2.6 \overline{1}--$ & $--\overline{10} \overline{2}--$ & \\
\hline 7 & Alabama & 2.50 & 0 & \\
\hline 8 & Nevada & 1.68 & 0 & \\
\hline 9 & Maryland & 1.57 & 1 & \\
\hline 10 & Arizona & 1.39 & 2 & \\
\hline 11 & Colorado & 1.38 & 1 & \\
\hline 12 & Washington & 1.20 & 0 & 75th Percentile (1.14) \\
\hline$\overline{13}$ & North Carolina & $1.1 \overline{2}$ & 0 & \\
\hline 14 & Kentucky & 1.11 & 0 & \\
\hline 15 & South Carolina & 1.02 & 1 & \\
\hline 16 & Utah & 1.01 & 2 & \\
\hline 17 & Virginia & 0.97 & 0 & \\
\hline 18 & Missouri & 0.93 & 0 & \\
\hline 19 & Oregon & 0.73 & 2 & \\
\hline 20 & Mississippi & 0.69 & 1 & \\
\hline 21 & Arkansas & 0.65 & 0 & \\
\hline 22 & Louisiana & 0.63 & 0 & \\
\hline 23 & Rhode Island & 0.58 & 0 & \\
\hline 24 & Texas & 0.51 & 4 & \\
\hline 25 & Oklahoma & 0.44 & 0 & 50th Percentile (0.42) \\
\hline$\overline{26}{ }^{-}$ & $\overline{\mathrm{New}}-\overline{\mathrm{J}} \overline{\mathrm{ersey}}$ & $\overline{0.4 \overline{1}}$ & 0 & \\
\hline 27 & Indiana & 0.37 & 0 & \\
\hline 28 & Ohio & 0.37 & 0 & \\
\hline 29 & Idaho & 0.32 & 0 & \\
\hline 30 & Michigan & 0.31 & 0 & \\
\hline 31 & West Virginia & 0.31 & 0 & \\
\hline 32 & Pennsylvania & 0.28 & 0 & \\
\hline 33 & New Mexico & 0.28 & 0 & \\
\hline 34 & Deleware & 0.28 & 0 & \\
\hline 35 & Illinois & 0.26 & 0 & \\
\hline 36 & South Dakota & 0.16 & 0 & \\
\hline 37 & Nebraska & 0.16 & 0 & \\
\hline 38 & Minnesota & 0.15 & 0 & 25th Percentile (0.14) \\
\hline$\overline{39}^{-}$ & $\overline{\text { Wisconsin }}-$ & $\overline{0.12}$ & 0 & \\
\hline 40 & Montana & 0.12 & 0 & \\
\hline 41 & Wyoming & 0.06 & 0 & \\
\hline 42 & Kansas & 0.05 & 0 & \\
\hline 43 & Maine & 0.05 & 0 & \\
\hline 44 & Vermont & 0.05 & 0 & \\
\hline 45 & North Dakota & 0.05 & 0 & 10th Percentile (0.04) \\
\hline$\overline{46}$ & $\overline{\text { Iowa }}---\cdots$ & $\overline{0.0 \overline{4}}$ & 0 & \\
\hline 47 & New York & 0.03 & 0 & \\
\hline 48 & New Hampshire & 0.00 & 0 & \\
\hline 49 & Connecticut & 0.00 & 0 & \\
\hline- & Alaska & - & 0 & \\
\hline - & National Mean & 1.06 & - & \\
\hline - & National Median & 0.43 & - & \\
\hline
\end{tabular}

a SLEV values in Hawaii and Massachusetts are skewed by these states having few counties (14 in MA, 5 in $\mathrm{HI}$ ) some of which have moderate (MA) to high (HI) species listings, but also very small areas. This yields a very high number of species listings per unit area, and a higher SLEV. 